PETER GOTTSCHALK

Boston College

ROBERT MOFFITT

Brown University

\title{
The Growth of Earnings Instability in the U.S. Labor Market
}

THE WIDENING EARNINGS distribution in the U.S. labor market over the 1970s and 1980s has been one of the most remarkable shifts in the structure of labor compensation in recent history-the last major shift in this distribution having occurred during the 1940s. ${ }^{1}$ In the postwar period, earnings and income distributions have been regarded as stable bedrock - that is, until recently — with a common theme being the stability of those distributions in light of massive changes in labor markets and public spending on redistributive programs. Entire books were written on the subject. ${ }^{2}$

This view of long-term stability has been dramatically altered by an enormous, and still growing, series of investigations showing a widening of the income and wage distributions. ${ }^{3}$ As documented in an article by Frank Levy and Richard Murnane, the widening of the earnings distribution began gradually in the 1970 s and accelerated in the 1980 s. ${ }^{4}$ Earnings differentials by education and experience grew rapidly in the 1980 s. A debate has now ensued concerning the causes of these trendswhether they are the result of general shifts in supply or demand caused by skill-biased technological change, shifts in the pattern of interna-

We would like to thank Bill Dickens and Larry Katz for comments, and Carol Kallman and Thomas Vanderveen for research assistance.

1. See Williamson and Lindert (1980) and Goldin and Margo (1992).

2. See, for example, Reynolds and Smolensky (1976).

3. Two of the earliest studies were Dooley and Gottschalk (1984) and Lawrence (1984).

4. Levy and Murnane (1992). 
tional trade, changes in union rents or the minimum wage, or other factors. ${ }^{5}$

Our study suggests that this literature has missed a critical aspect of the widening wage distribution: a growing instability in wages has caused a major part of the trend. The fact that annual cross-sectional "snapshots" of the work force over the 1970s and 1980s reveal an increase in the variance, and other measures of dispersion, of the wage distribution has been interpreted as reflecting solely an increase in the dispersion of average—or what we call "permanent"—wages. We show, instead, that part of the increase in the annual variance of wages for white men has resulted from an increase in the variance of short-term changes in earnings-or "transitory" movements in earnings. We show that an increase in earnings instability has effected a full one-third to one-half of the widely noted increase in the variance of earnings from the 1970 s to the 1980 s.

The recognition of a major upturn in earnings instability prompts many further questions. Does it reflect a true increase in the instability of wage rates, or just an increase in employment turnover or job mobility? Does it reflect an increase in "voluntary" or "involuntary" movements between jobs? Is it concentrated in particular sectors of the economy? Is it associated with aggregate shocks or sectoral shocks, or is it entirely idiosyncratic on an individual level?

We shall provide partial and suggestive answers to these and other questions and present an exploratory investigation of causes. Despite the limited nature of our inquiry, it is unambiguously clear that this search for the causes of the growing instability will lead in a very different direction from that which the literature has taken thus far. For example, while an increase in the price of "skill" may be a satisfactory explanation for changes in the dispersion of permanent wages, it does not explain the patterns of instability growth that we find. Similarly, supply shifts, which are unlikely to cause high-frequency fluctuations in the return to labor, are not likely to explain greater instability in earnings. More likely candidates for explaining "global" increases in instability are the decline in regulation, the decline in unionization, the disappearance of administrated prices, and general increases in competition

5. See, for example, Blackburn, Bloom, and Freeman (1990), Bound and Johnson (1992), Davis and Haltiwanger (1991), Katz and Murphy (1992), and Murphy and Welch (1992). 
Figure 1. Earnings Distribution of Working Men, 1979 and $1987^{\text {a }}$

Percentage

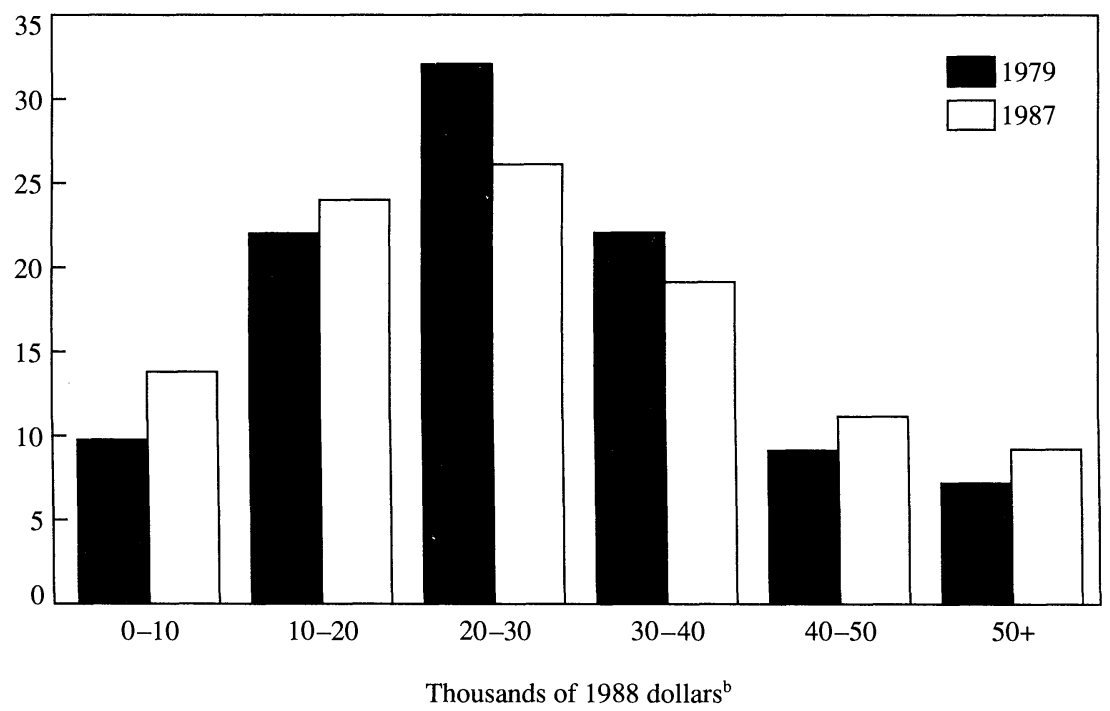

Source: Levy and Murnane (1992, figure 1).

a. Sample includes white men aged $25-54$ who received wages and salaries, and it is restricted to wage and salary income.

b. Inflation adjustments made using the personal consumption expenditure deflator.

within industries and from abroad (which may be associated with instability in the labor market). We touch on these and other issues, but they clearly remain fruitful areas for future, more in-depth research.

\section{Basic Patterns of Instability}

Figure 1, taken from the literature review of Levy and Murnane, shows the growing dispersion of working men's real annual earnings. ${ }^{6}$ Between 1979 and 1987, the median of the earnings distribution remained more or less fixed, reflecting the slow growth of male earnings in the United States over the period, but the proportions of men in the bottom and in the top of the distribution rose and the proportion in the middle fell.

6. Levy and Murnane (1992). 
Our interest is in determining how much of this increase in dispersion has arisen from a rise in the dispersion of transitory earnings movements as opposed to a change in the dispersion of "permanent" earnings. To make these concepts more precise, we call upon the traditional distinction between the permanent and transitory components of a variable. ${ }^{7}$ Define $y_{i t}$ as the $\log$ of real annual earnings of individual $i$ in year $t$. A standard permanent-transitory decomposition can be written as follows:

$$
y_{i t}=\mu_{i}+\nu_{i t},
$$

where $\mu_{i}$ is permanent earnings, which does not vary with $t$, and $\nu_{i t}$ is transitory earnings, which does vary over time. The variance of $y_{i t}$ is equal to the sum of the variance of permanent log earnings, $\operatorname{var}\left(\mu_{i}\right)$, and the variance of transitory earnings, $\operatorname{var}\left(\nu_{i t}\right)$. Because figure 1 and similar figures in the literature represent only "snapshots" of the work force-a static comparison of the distribution at two separate points in timethey measure only the change in the total variance of log earnings, $\operatorname{var}\left(y_{i t}\right)$. The question we wish to ask is how much of that change has arisen from a change in $\operatorname{var}\left(v_{i t}\right)$ as opposed to a change in $\operatorname{var}\left(\mu_{i}\right)$.

As we noted in the introduction, the universal assumption in the literature has been, implicitly, that the predominant influence on changes in the total variance has been an increase in the variance of permanent earnings. An increase in the price of "skill," for example, which is presumably determined by gradual movements in demand, implies that permanent earnings are affected; there is no reason to expect that such a price increase would cause wages to fluctuate more from year to year, nor is the fluctuation in the stock of skills likely to increase. To some extent, the presumption in the literature of an increase in the variance of permanent earnings is based on evidence showing that earnings differentials by education have grown, since individual levels of education do not change much over the adult lifetime. ${ }^{8}$ Although the growth in these differentials does constitute evidence that the variance of permanent earnings has increased, it is not inconsistent with an increase in transitory earnings variance that is equal to or greater than that of permanent

7. These concepts are familiar since their formulation for income and consumption by Friedman (1957).

8. However, a stronger piece of evidence is probably that of Cutler and Katz (1992), who found an increase in the dispersion of consumption as well as income. We use sample weights in all our analyses to control for the oversampling. See Hill (1992) for an overview of the PSID. 
earnings. The transitory component of earnings within education classes could be growing, or differentials between education classes could be fluctuating more around an upward trend.

A practical issue that naturally arises is how to define "permanent" earnings when its variance is changing. We follow standard practice by simply averaging an individual's earnings over several years to arrive at an estimate of permanent earnings. By calculating this average over different calendar periods, we can determine whether the distribution of permanent earnings has changed. Within each time period, we can compute a set of transitory components for each individual-the deviations of an individual's earnings around his mean-and determine whether the variance of these deviations has changed across periods.

\section{Characteristics of Sample}

To conduct such an exercise requires the availability of panel, or longitudinal, data that have repeated measures of earnings on the same individuals, rather than the successive cross-sections of the Current Population Survey (CPS), which have dominated the literature. We use the Michigan Panel Study on Income Dynamics (PSID), the oldest and most comprehensive panel data on the earnings and income of a set of U.S. families and individuals. The PSID began by interviewing approximately 5,000 U.S. families in 1968, with an oversample from the lowincome population but also a representative sample from the entire population. Families have been interviewed annually since that time, and individuals who have left their original families to form new families or to join other families have been followed and interviewed as well. Also, children who were present in 1968, or who were born into sample families, have been followed as they age and eventually leave the parental home. Thus, the sample stays representative of the U.S. population, except for post-1968 immigration. Attrition to date has been significantapproximately 50 percent-but has caused surprisingly little bias. ${ }^{9}$

We select only white males from the survey in order to focus on the group most frequently examined in past work. This group also has rather stable labor market patterns and therefore lower transitory fluctuations

9. See Becketti and others (1988) and Fitzgerald, Gottschalk, and Moffitt (1994). The attrition has been mostly related to observables, and the sample weights have been adjusted to account for this selection. 
than some other labor force groups. We take all such men who were aged 20-59 in any year between 1970 and 1988, who had positive wage and salary earnings, who were heads of household, and who were not students (all of which are likely to decrease volatility). There are 2,730 such men in the sample. ${ }^{10}$ At the interview date in each year, the household head was asked questions regarding annual earnings, weeks of work, and other income and labor force activity during the prior calendar year. The earnings information in the data thus applies to the years 1969-87. We deflate all dollar values by the GNP personal consumption expenditure deflator (using 1982 as the base year). ${ }^{11}$

In prior work, we validated the patterns of the cross-sectional variances of log earnings in the PSID by treating the sample as a set of crosssections and by comparing their year-to-year values with the same variances in the CPS for a comparable sample (same age, race, and sex). ${ }^{12}$ This work indicated that the PSID tracks the CPS quite well, showing upward trends in log earnings variances in the 1970s and accelerating trends in the 1980s. Thus, total variances trend similarly in the CPS and PSID; but only with the PSID can the relative importance of permanent and transitory variances be determined.

To compute permanent and transitory log earnings variances and how they have changed over time, we subdivide the data into two nineyear periods, 1970-78 and 1979-87. Within each period, we calculate for each individual the mean of his log earnings over all nine years and the deviation of his log earnings from his mean in each year. We then compute the variance of permanent log earnings as the variance of the means across individuals. We compute the variance of transitory log earnings by computing the variance of the nine transitory components separately for each individual and by then averaging them across individuals. ${ }^{13}$

10. We omit 1968 and 1969 because only labor income is available in the data, which have sources that may reflect capital income, such as the labor parts of farm income and of roomers and boarders. We end in 1988 because that was the most recent survey wave available at the time we began our analysis. Note that we include men for all years for which there are data available. Because some men turn age 20 during the time period and others turn 59, and because of attrition, not all men have a full 19 years of data.

11. We also delete outliers by trimming the top and bottom 1 percent of the earnings distribution within age-education-year cells.

12. See Gottschalk and Moffitt (1992).

13. Computed in this way, we obtain a separate transitory variance for each individual. There are standard formulas for these variances. The ones we use are given in the appendix. 
Table 1. Variances of Permanent and Transitory Real Annual Earnings, 1970-87

\begin{tabular}{|c|c|c|c|c|c|c|c|c|}
\hline \multirow[b]{2}{*}{$\begin{array}{c}\text { Sample } \\
\text { definition }\end{array}$} & \multicolumn{4}{|c|}{ Permanent variance } & \multicolumn{4}{|c|}{ Transitory variance } \\
\hline & $1970-78$ & $1979-87$ & Change & $\begin{array}{l}\text { Percent } \\
\text { change }\end{array}$ & $1970-78$ & $1979-87$ & Change & $\begin{array}{l}\text { Percent } \\
\text { change }\end{array}$ \\
\hline All & 0.201 & 0.284 & 0.083 & 41 & 0.104 & 0.148 & 0.044 & 42 \\
\hline \multicolumn{9}{|c|}{ Years of completed education } \\
\hline Fewer than 12 & 0.175 & 0.272 & 0.097 & 55 & 0.106 & 0.208 & 0.102 & 96 \\
\hline 12 or more ${ }^{b}$ & 0.161 & 0.216 & 0.055 & 34 & 0.081 & 0.123 & 0.042 & 52 \\
\hline 16 or more & 0.184 & 0.200 & 0.016 & 9 & 0.065 & 0.093 & 0.028 & 43 \\
\hline \multicolumn{9}{|l|}{ Age } \\
\hline 20-29 & 0.133 & 0.225 & 0.092 & 69 & 0.130 & 0.182 & 0.052 & 40 \\
\hline $30-39$ & 0.208 & 0.238 & 0.030 & 14 & 0.085 & 0.125 & 0.040 & 47 \\
\hline $40-49$ & 0.203 & 0.307 & 0.104 & 51 & 0.063 & 0.118 & 0.055 & 87 \\
\hline \multicolumn{9}{|c|}{ Permanent earnings percentile } \\
\hline Lowest 25 percent & $\ldots$ & $\ldots$ & $\ldots$ & $\ldots$ & 0.229 & 0.337 & 0.108 & 47 \\
\hline 25-75 percent & $\ldots$ & $\ldots$ & $\ldots$ & $\ldots$ & 0.075 & 0.097 & 0.022 & 29 \\
\hline Top 25 percent & $\ldots$ & $\ldots$ & $\ldots$ & $\ldots$ & 0.045 & 0.054 & 0.009 & 20 \\
\hline
\end{tabular}

We modify this procedure in one respect to avoid contaminating the permanent and transitory measures by normal life-cycle earnings growth, since, prior to retirement, earnings generally increase with age. We first regress the earnings values for all individuals and in all years on a quartic in age. (Separate regressions are estimated for the two nineyear periods.) We then compute the residuals from these regressions and use them for the permanent and transitory variance calculations. The permanent variance thus represents the dispersion of average individual earnings around a common age-earnings profile, and the transitory variance represents the dispersion of fluctuations around each individual's age-earnings profile. ${ }^{14}$

\section{Results}

The first row of table 1 shows the results of our calculations. Between the two periods (from 1970-78 to 1979-87), the permanent variance rose from 0.20 to 0.28 , a 41 percent increase. This is strong evidence that the

14. The individual's age-earnings profile differs from the common profile only by being shifted up or down. Below, we report estimates that result when each individual is permitted a separate slope as well. 
Figure 2. Distribution of Permanent Earnings, 1970-78 and 1979-87

Percent

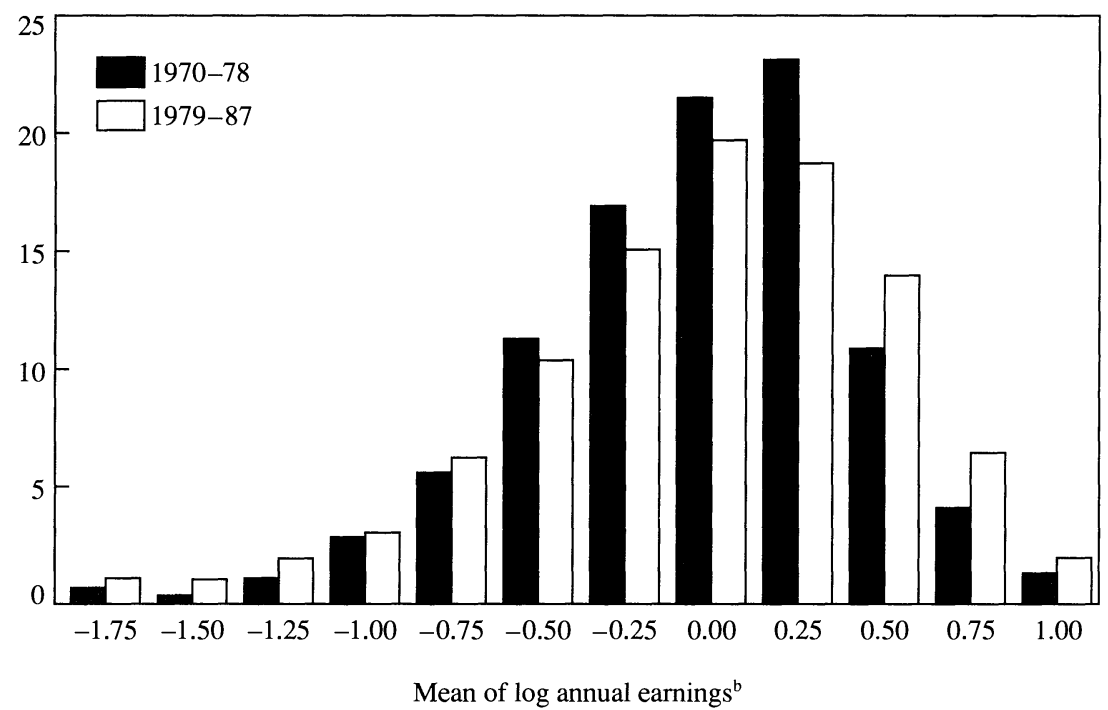

Source: Authors tabulation of annual earnings of white male heads of households in the PSID. For a fuller description of the sample, see the text.

a. The figure shows the distribution of individuals' means of $\log$ annual earnings over each of the two periods.

dispersion of permanent earnings rose from the 1970s to the 1980s, consistent with many explanations that have been suggested for the trend in earnings inequality. However, the results also indicate that the transitory variance, although only half as large as the permanent variance, rose as well, from 0.10 to 0.15 , or by 42 percent, which is almost exactly the same growth rate as that of the permanent variance. Since the two variances sum to the total cross-sectional variance, our results thus indicate that fully one-third of the widening of the earnings distribution has resulted from a rise in the instability of earnings. ${ }^{15}$

Figures 2-5 show the shifting distribution of the permanent and tran-

15. The alternative methodology used in Moffitt and Gottschalk (1993) indicates that half of the absolute increase is attributable to changes in the permanent component. However, the percent increase is particularly relevant if the correlation coefficient between earnings in adjacent years is of interest. That the permanent and transitory components have risen by the same percent implies that that correlation coefficient has remained more or less level at about 0.66 ; in other words, the fraction of the total variance that is constituted by the permanent variance has not changed. As a separate matter, this also implies that short-term earnings mobility has not changed. 
Figure 3. Changes in the Distribution of Permanent Earnings between 1970-78 and 1979-87

Percent change

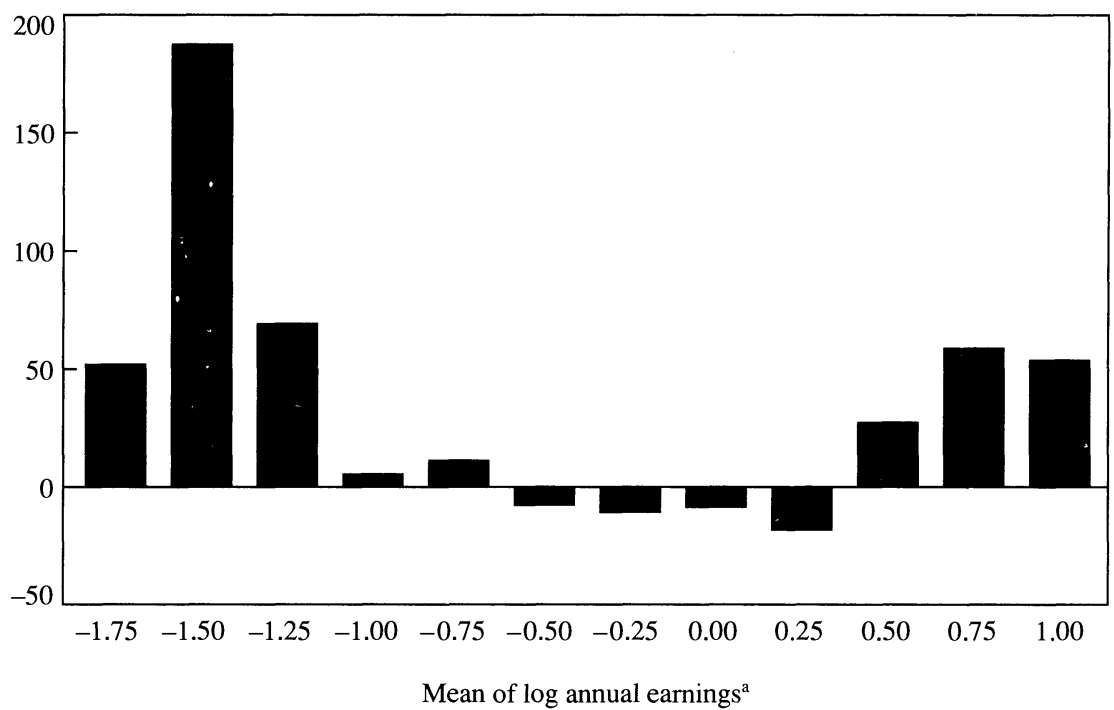

Source: Authors' tabulation of annual earnings of white male heads of households in the PSID. For a fuller description of the sample. see the text.

a. Mean annual earnings are measured as deviations of an individual's log annual earnings from his age-specific profile.

sitory components in more detail. Figure 2 demonstrates that the fraction of men with individual mean (that is, permanent) log annual earnings in the middle of the distribution has fallen, and the fraction of men in both tails has risen. This is similar to the pattern found for overall earnings, which was shown in figure 1 . Figure 3 , which shows the percent change in each of the vertical bars in figure 2, shows even more clearly the increasing dispersion, particularly in the lower tail. Figures 4 and 5 illustrate the distributional shifts in the transitory component of earnings. ${ }^{16}$ Both figures show a sharp decline between the two periods in the proportion of the white male work force experiencing relatively small transitory shifts in earnings and a sharp increase in the proportion of men experiencing large transitory fluctuations (whether positive or negative). The fraction of men with the largest fluctuations has risen particularly dramatically.

16. The standard deviation is plotted instead of the variance. 
Figure 4. Distribution of Individuals' Standard Deviations of Transitory Earnings, 1970-78 and 1979-87

Percent

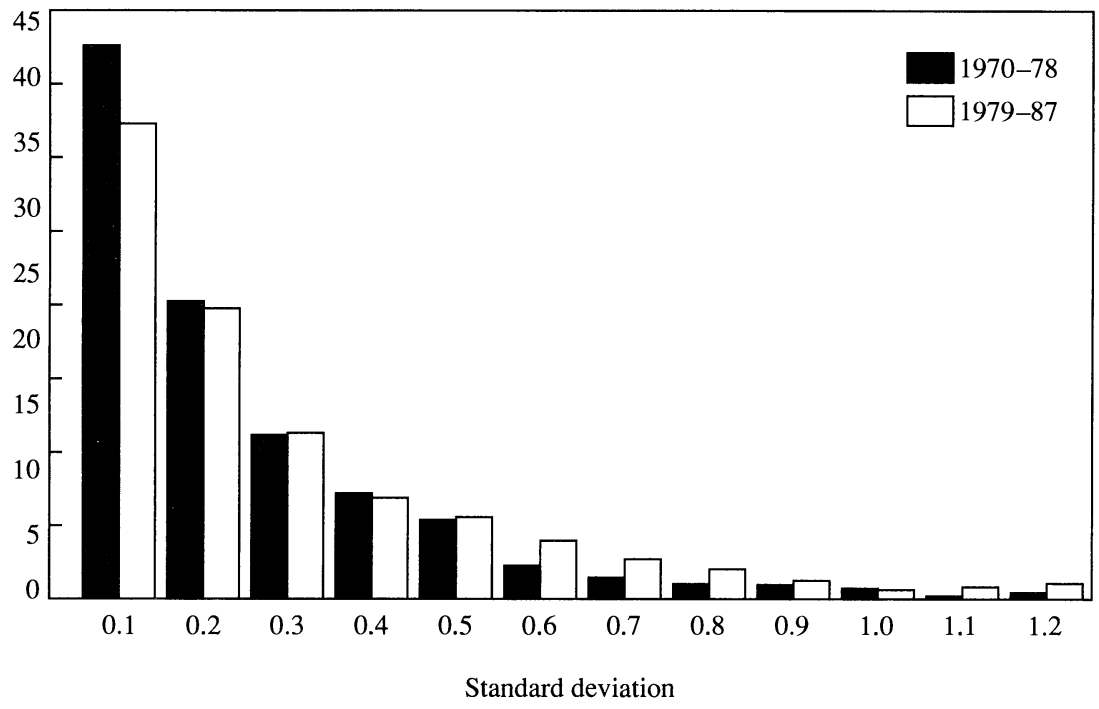

Source: Authors' tabulation of annual earnings of white male heads of households in the PSID. For a fuller description of the sample, see the text.

The remaining portion of table 1 shows how the two components have changed within various subgroups. The earnings distribution has widened within all education groups, although particularly so among lesseducated men. However, the relative importance of permanent and transitory components within education groups varies greatly. In both absolute and percentage terms, the increase in transitory fluctuations has been the greatest among less-educated males, but that group has also experienced marked increases in the dispersion of permanent earnings. (In percentage terms, the increases in transitory variance exceed the permanent increases.) Nevertheless, it is important to note that the variance of transitory earnings has increased for the most highly educated men as well. In addition, both permanent and transitory variances have risen within all age groups, although more uniformly.

The bottom three rows of the table show the increases in transitory variance among men in different percentiles of the permanent earnings distribution. The results show the increase in transitory variance to have been greatest among those with the lowest permanent earnings. But, 
Figure 5. Changes in the Distribution of Individuals' Standard Deviations of Transitory Earnings between 1970-78 and 1979-87

Percent change

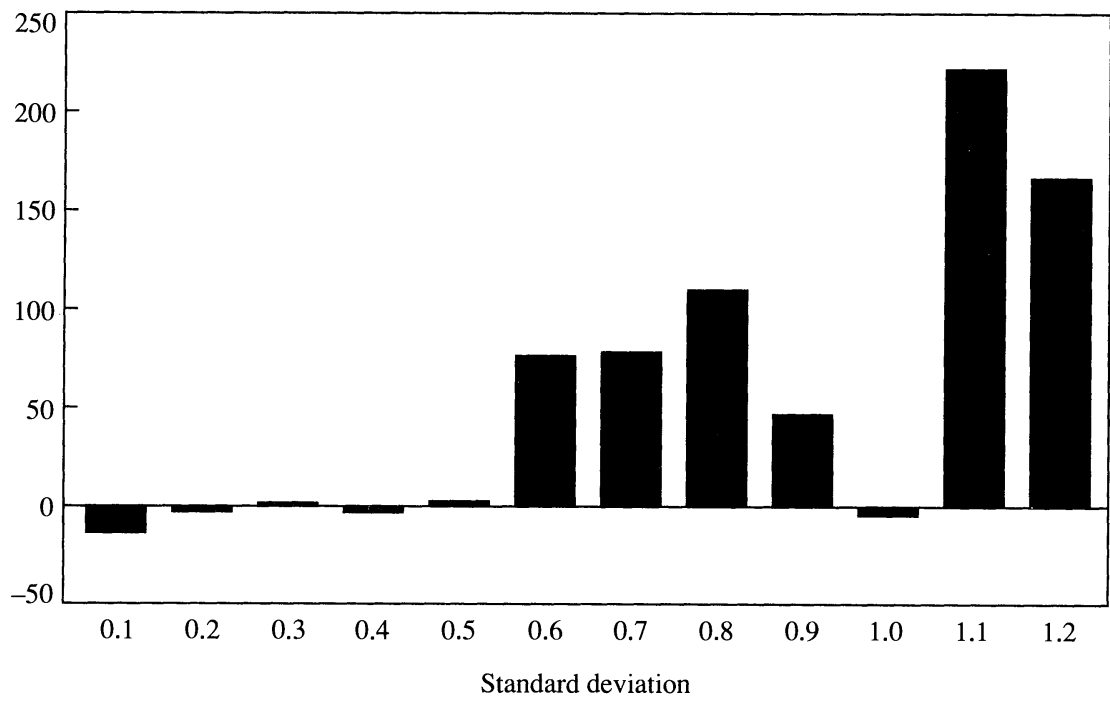

Source: Authors' tabulation of annual earnings of white male heads of households in the PSID. For a fuller description of the sample, see the text.

once again, even workers with the highest permanent earnings experienced some increase in the dispersion of transitory earnings, reflecting a general upward shift in volatility.

Before proceeding further, it is worth asking whether any of our results could be attributed to poor data quality. Most obvious, the transitory components we have calculated undoubtedly contain a large degree of measurement error, as survey respondents inaccurately recall earnings in the prior year. Studies of measurement error in earnings responses in panel data, including studies of the PSID, indicate that yearto-year changes indeed have considerable error. John Bound and Alan Krueger, using administrative data from the Social Security Administration as "true," and Bound and others, using administrative records from a large firm as "true," estimate that the variance of true year-to-year changes in annual earnings is about two-thirds of the variance of reported year-to-year changes. ${ }^{17}$ Although this implies that the transitory

17. Bound and Krueger (1991) and Bound and others (1994). 
variances we calculate are unquestionably biased upward, the issue is whether this bias has changed over time. We know of no evidence that it has. The PSID questions about the past year's earnings have not changed much over time, nor is there any reason to suspect that respondents themselves have become more erroneous in their reporting over time; in fact, most survey research indicates that respondents become more accurate the longer they remain in the survey. Nor has the treatment of imputed earnings changed over time in the PSID; and, in any event, the fraction of cases with missing earnings is too small to explain the magnitude of the trends we have observed. ${ }^{18}$ Therefore we conclude that data quality is not a promising candidate to explain our results.

Another issue concerns whether the components we have identified as "transitory" are indeed serially uncorrelated over time. The evidence from our data indicates that they are largely uncorrelated. The correlation coefficient between successive transitory components is only 0.14 in the first calendar period and 0.18 in the second, representing an $\mathrm{R}^{2}$ of only 0.02 in a regression of each component on its first-order lag. In addition, we recomputed the residuals used for the calculation of the permanent and transitory variances by estimating log earnings regressions that allow each individual to have his own unique age-earnings profile in each calendar period rather than a common population ageearnings profile. This allows us to avoid confusing our measures of transitory variance with individual trends. The resulting transitory variances are lower in absolute magnitude than those calculated aboveabout 0.03 -indicating that there is some individual variation in ageearnings slopes. However, the transitory variance still increases from the first calendar period to the second by 40 to 60 percent, about the same as that estimated previously; thus, there is little effect on the trend.

Finally, in a separate analysis, we estimated a more formal model of the time-series structure of individual earnings, allowing the permanent effect to follow a random walk and allowing the transitory component to be serially correlated according to a general $\operatorname{ARMA}(p, q)$ process (auto-

18. Only 1.6 percent of the sample has imputed earnings. This fraction is undoubtedly low because our population comprises only white males, who report more accurately than some other groups. More important, this fraction has not changed over time. Nor have the PSID imputation methods changed; the same coding instructions for imputation have been used since 1968. 
regressive moving-average process). ${ }^{19}$ The estimates from that model show that individual earnings follow a random walk but one with a low intertemporal covariance (apart from the average individual effect) and show that the transitory component follows an ARMA $(1,1)$ process but again with a low correlation coefficient. Thus, we found little evidence of serial correlation even in a more structural model of the earnings process.

A somewhat related issue concerns whether our choice of two nineyear intervals, 1970-78 and 1979-87, masks trends within each interval that might be incorrectly attributed to transitory variance. To examine this possibility, we calculated a five-year moving average of earnings as our estimate of individual permanent earnings; thus, we have a year-byyear permanent earnings estimate, not one averaged over an arbitrary nine-year period. We then calculated transitory components as the difference between actual earnings and permanent earnings, again on a year-by-year basis. The resulting transitory variance increases from 0.05 in 1974 to 0.11 in 1986, and the permanent variance increases from 0.27 to 0.41 over the same interval. Thus, the relative sizes of the increase remain the same as before; indeed, the transitory variance increases more in percentage terms.

\section{Other Issues}

A more substantive economic issue is whether the increase in transitory fluctuations is purely cyclical. In our construction of transitory components, we have intentionally not removed cyclical effects. However, the distributional effects of downturns are well known, and for that reason it should be expected that transitory variances will be countercyclical. As such, the issue is how the 1974-76 and 1981-83 downturns affect the trends we have calculated.

To assess this issue, we calculate year-by-year transitory variances. Since we have composed a transitory earnings component for each individual in each year, we simply calculate the variance of those components across all individuals in each year. ${ }^{20}$ Figure 6 shows the time pro-

19. See Moffitt and Gottschalk (1993).

20. Note that the transitory components in a given year, as we have calculated them, do not sum to zero across people; they only sum to zero over years for each individual. The year-specific transitory variance we now calculate, however, takes out the annual mean of those components. Thus, our transitory variances will not pick up cyclical movement in the aggregate mean of earnings, only in the variance of earnings around that mean. 
Figure 6. Variance of Transitory Annual Earnings and Transitory Weekly Wages with Unemployment Rate, 1970-87

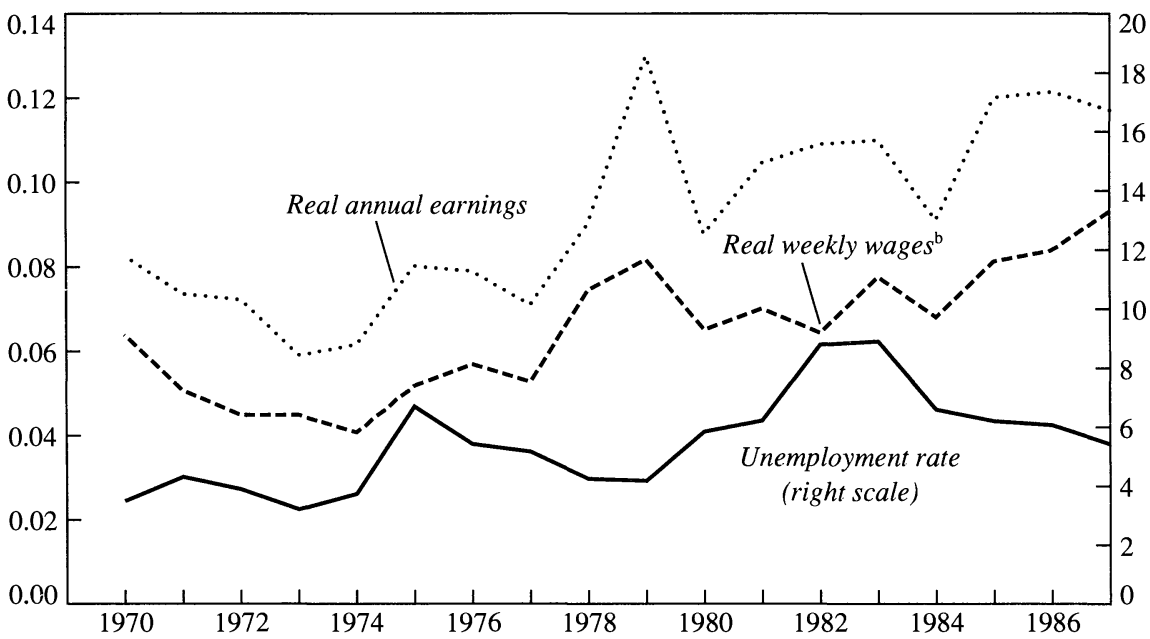

Source: Authors' tabulation of annual earnings of white male heads of households in the PSID. Unemployment rate is taken from the Economic Report of the President 1993, table B.37, p. 390.

a. Figure depicts real log annual earnings and real log weekly wages.

b. Weekly wages are annual earnings divided by the number of weeks worked.

file of these transitory variances, along with the national unemployment rate for men aged 20 and older. The figure has several important features. First, the transitory variance is indeed countercylical around the two recessions, rising sharply from 1974 to 1975 and from 1980 to $1983 .{ }^{21}$ Second, although no particular trend in the variance is apparent during most of the 1970s (through about 1978), there is clear evidence of an increase between the 1970 s as a decade and the 1980s as a decade. Third, within the 1980s, a particularly marked divergence between the unemployment rate and the transitory variance occurred after 1984, as the transitory variance continued to rise during the recovery. Indeed, by 1985 the transitory variance had reached a level exceeding that of the $1980-83$ recession.

21. The spike in 1979 is partly an artificial result because of its location on the boundary of one of our chosen calendar time intervals and because permanent earnings for 1979 are based on the entire 1979-87 period. When the moving-average measure of permanent earnings described previously is used, the 1979 spike is greatly reduced. However, the strong upward trend remains, both in figure 6 and in the moving-average estimates, when 1979 is removed. 
These patterns are consistent with patterns found in previous studies of earnings inequality in the United States. Many of the shifts in observed skill differentials, for example, have been shown to be a product of the $1980 \mathrm{~s}$, not the $1970 \mathrm{~s} .{ }^{22}$ The continued rise of the transitory variance during the post-1983 recovery, which shows that the increase in the 1980 s did not simply reflect cyclical factors, has been connected with the general widening of the cross-sectional wage distribution, which some observers initially thought to be cyclical as well. Work showing that the poverty rate failed to return to its prerecessionary level may also indicate that some type of structural shift took place in the 1980s. ${ }^{23}$

What these commonalities suggest is that the permanent and transitory components appear to have risen at approximately the same time, which in turn suggests that independent forces may not be driving them. For example, one might imagine that "good" jobs have not only high pay but also fairly stable employment and wages, while "bad" jobs have low pay and are unstable. An increase in the number of "bad" jobs, for example, would increase both the permanent and transitory variance. (We examine this issue in the next section when we examine whether transitory variances have increased within "bad" and "good" jobs.)

Even with the evidence at hand, however, our results do not appear fully consistent with a good jobs-bad jobs paradigm. For example, to the extent that there has been an equal-sized increase in both good and bad jobs-that is, an increase in the number of men at the top and bottom of the permanent earnings distribution-there should be no net increase in transitory variance. However, we have found such an increase, in part because transitory variances have increased even for workers with high permanent earnings. In addition, the literature strongly suggests that the quantities as well as prices of labor have shifted toward high-paying jobs and away from low-paying jobs, as would occur under a skill-biased shift in labor demand. ${ }^{24}$ If anything, therefore, a shift toward high-paying jobs, which have lower transitory variances, should reduce net earnings volatility, not increase it as we found.

A related issue is whether the increase in transitory variance has arisen merely from an increase in the instability of employment, as op-

22. See Levy and Murnane (1992).

23. Cutler and Katz (1991).

24. Katz and Murphy (1992). 
posed to an increase in the instability of wage rates. Since it is well known that employment is the predominant force behind cyclical fluctuations in earnings, we examine whether the continued increase in transitory variance arises from employment or wage fluctuations, especially for the later 1980s. To answer this question, we decompose annual earnings into weekly wages and weeks worked during the year. ${ }^{25}$ For each individual in each of our two subperiods (1970-78 and 1979-87), we compute an average, and a set of deviations around that average, for both annual weeks worked and real weekly wages. ${ }^{26}$ These are then used to calculate permanent and transitory variances for the two subperiods as before. ${ }^{27}$

Table 2 shows the results of this exercise. Interestingly, the table shows that the transitory variances of both real weekly wages and annual weeks of work increased between the periods. Indeed, when comparing the logarithmic versions of both, so that their relative magnitudes can be compared, the absolute change in the transitory variance of log wages was slightly larger than the absolute change in the transitory variance of the log of weeks worked. The table also shows transitory variances of the absolute number of weeks worked. For example, the standard deviation of the transitory component of weeks worked went up from approximately 6.1 to approximately 6.7 between the periods (the square roots of 37.8 and 44.6 , respectively). However, once again, the results show that the dispersion of the permanent components of both variables also increased between the periods. For weeks worked, this implies that the dispersion in the average number of weeks each individual worked during the year has increased. ${ }^{28}$ Nevertheless, the most im-

25. We do not examine the influence of hours worked per week at this time. We address that topic in the next section, where we study the influence of increasing part-time work.

26. As with annual earnings, we use deviations around age profiles.

27. For weeks of work, we should note that our variance calculations do not measure, nor in any way reflect, the decline in mean weeks worked in the U.S. work force that has occurred over the 1970s and 1980s (Juhn, Murphy, and Topel, 1991). Our estimates of the trend in the dispersion of "permanent" weeks of work, however, do reflect the fact that the weeks-worked decline has been concentrated among the lowest-skilled groups. Nevertheless, the trend in the transitory variance, which is our major object of interest, has no necessary relation to trends in the aggregate level of weeks worked or in the dispersion of its permanent component.

28. If the change in the dispersion of average weeks worked is interpreted as a labor supply response to the change in the dispersion of weekly wages, the implied uncompensated wage elasticity is about 0.30 . 
Table 2. Variances of Permanent and Transitory Real Weekly Wages and Annual Weeks of Work, 1970-87

\begin{tabular}{|c|c|c|c|c|c|c|c|c|}
\hline \multirow[b]{2}{*}{ Variable } & \multicolumn{4}{|c|}{ Permanent variance } & \multicolumn{4}{|c|}{ Transitory variance } \\
\hline & $1970-78$ & $1979-87$ & Change & $\begin{array}{l}\text { Percent } \\
\text { change }\end{array}$ & $1970-78$ & $1979-87$ & Change & $\begin{array}{l}\text { Percent } \\
\text { change }\end{array}$ \\
\hline Log weekly & & & & & & & & \\
\hline wage & 0.171 & 0.230 & 0.059 & 35 & 0.075 & 0.101 & 0.026 & 35 \\
\hline $\begin{array}{l}\text { Log of } \\
\text { weeks worked }\end{array}$ & 0.014 & 0.020 & 0.006 & 43 & 0.046 & 0.063 & 0.017 & 37 \\
\hline $\begin{array}{l}\text { Number of } \\
\text { weeks worked }\end{array}$ & 15.8 & 17.8 & 2.0 & 13 & 37.8 & 44.6 & 6.8 & 18 \\
\hline
\end{tabular}

Source: Authors' calculations from the PSID.

a. Earnings data are deflated to 1988 dollars.

portant conclusion from table 2 is that roughly half of the increase in the variance of transitory annual earnings is a result of an increase in the variance of weekly wage rates. ${ }^{29}$

Figure 6 shows the year-by-year profiles of the transitory variance of real log weekly wages. The pattern matches that for annual earnings discussed previously: there is clear evidence of an upward trend in the 1980 s, with a particularly striking upturn in the transitory variance over the postrecession period. In fact, the post-1984 surge for the transitory variance of weekly wages is even sharper than that for annual earnings. ${ }^{30}$

\section{Correlates of Transitory Fluctuations}

A natural direction in which to take our investigation of the increase in transitory fluctuations is to determine whether it has been associated with other observable individual characteristics or labor market outcomes. For example, one suspects that earnings are more variable in industries such as construction and wholesale and retail trade than in pub-

29. We should note that we have excluded observations with zero weeks worked from these calculations. However, only 3-4 percent of men are in this category, a figure similar to the CPS estimate for men of 4.8 percent (Juhn, Murphy, and Topel, 1991). Thus, any effects from this source are inconsequential in magnitude.

30. A figure for weeks worked is not shown. However, its variance follows the unemployment rate very closely, even in the latter part of the 1980s. The main evidence for an increase in its variance in the 1980s is simply that, by 1987, that variance had not fallen back to its levels in the 1970 s. 
lic administration. Changes in industry structure may, therefore, affect aggregate measures of variability through compositional effects. Likewise, if unionized workers have more stable earnings than nonunionized workers, then the well-known secular decline in the rate of unionization would lead to increased earnings variability. Another possibility is that persons who changed jobs have experienced larger fluctuations in earnings if they moved across sectors with different sector-specific shocks or across jobs in firms with different job-specific shocks. Some of these issues can be examined with the same data-the PSID-that we used to estimate the general patterns of transitory fluctuations.

\section{Industrial Composition and Unionization}

Table 3 presents the variance of men's transitory earnings by industry and union status. ${ }^{31}$ The first three columns describe our full sample, while the last three exclude part-time workers and the self-employed. ${ }^{32}$ These data show that workers not represented by a union had transitory variances that were substantially higher than those who were represented $(0.099$ versus 0.052 in the first period and 0.133 versus 0.075 in the second period). While this implies that the shift toward nonunionized jobs increased the overall transitory variance, this is not a full explanation since the transitory variance increased both for unionized workers and nonunionized ones. Similarly the shift out of manufacturing jobs and into service and trade jobs accounts for only part of the overall increase. While manufacturing had relatively stable earnings $(0.050)$ compared with growing sectors, such as services $(0.121)$ and trade (0.108), all sectors experienced an increase in transitory fluctuations.

The last three columns exclude individuals who worked fewer than 35 hours a week and persons with self-employment income. Since the self-employed have substantially higher transitory variances than the non-self-employed and part-time workers have greater transitory variance than full-time workers, their exclusion reduces the transitory vari-

31. Variances by union status are only shown for those industries with more than 100 observations for each status in both periods.

32. Recall that, since our sample only includes men with positive wage and salary income, those who have only self-employment income are excluded throughout. The exclusions here are men who have both wage and salary income as well as self-employment income. 
Table 3. Variance of Transitory Annual Earnings by Industry and Union Status, $1970-87$ a

\begin{tabular}{|c|c|c|c|c|c|c|}
\hline \multirow{2}{*}{$\begin{array}{l}\text { Industry and } \\
\text { union status }\end{array}$} & \multicolumn{3}{|c|}{ All workers } & \multicolumn{3}{|c|}{$\begin{array}{c}\text { Full time, not } \\
\text { self-employed workers }\end{array}$} \\
\hline & $1970-78$ & $1979-87$ & Change & $1970-78$ & $1979-87$ & Change \\
\hline All industries & 0.085 & 0.118 & 0.033 & 0.063 & 0.092 & 0.029 \\
\hline Unionized & 0.052 & 0.075 & 0.023 & 0.049 & 0.071 & 0.022 \\
\hline Nonunionized & 0.099 & 0.133 & 0.034 & 0.070 & 0.100 & 0.030 \\
\hline Construction & 0.161 & 0.181 & 0.020 & 0.145 & 0.144 & -0.001 \\
\hline Nonunionized & 0.181 & 0.194 & 0.013 & $\cdots$ & . . & $\cdots$ \\
\hline Manufacturing & 0.050 & 0.095 & 0.045 & 0.046 & 0.088 & 0.042 \\
\hline Unionized & 0.056 & 0.079 & 0.023 & $\ldots$ & $\ldots$ & $\ldots$ \\
\hline Nonunionized & 0.045 & 0.102 & 0.057 & 0.040 & 0.094 & 0.054 \\
\hline $\begin{array}{l}\text { Transportation, communication, } \\
\text { and public utilities }\end{array}$ & 0.049 & 0.082 & 0.033 & 0.049 & 0.070 & 0.021 \\
\hline Unionized & 0.035 & 0.062 & 0.027 & $\ldots$ & $\ldots$ & $\ldots$ \\
\hline Nonunionized & 0.058 & 0.097 & 0.039 & 0.048 & 0.077 & 0.029 \\
\hline $\begin{array}{l}\text { Wholesale and } \\
\text { retail trade }\end{array}$ & 0.108 & 0.149 & 0.039 & 0.081 & 0.105 & 0.024 \\
\hline Services & 0.121 & 0.132 & 0.011 & 0.091 & 0.093 & 0.002 \\
\hline Nonunionized & 0.136 & 0.146 & 0.010 & 0.102 & 0.101 & -0.001 \\
\hline Public administration & 0.041 & 0.068 & 0.027 & 0.026 & 0.062 & 0.036 \\
\hline
\end{tabular}

Source: Authors' calculations from the PSID.

a. Industries and union-nonunion sectors with fewer than 100 observations are not shown. Earnings data are deflated to 1988 dollars.

ance in each subperiod ${ }^{33}$ Furthermore, since both of these groups with above-average transitory fluctuations have been growing, their exclusion also lowers the overall growth in transitory variance. However, the pattern of increase remains largely the same. Earnings became more variable in all industries-other than construction and nonunionized services-even for full-time workers with no self-employment income.

In order to obtain a rough measure of the importance of interindustry shifts, we decompose the total change in the variance of transitory earnings into changes in the composition of the work force across industryunion cells and changes in the transitory variance within cells. This standard decomposition uses the base-period weights to calculate the variance that would have occurred if the industry-union structure had been

33. These transitory variances, not shown in table 3 , are 0.289 for the self-employed versus 0.089 for the non-self-employed, and 0.311 for part-time workers versus 0.104 for full-time workers. 
the same in the second subperiod as in the first but if transitory variances within industry-union cells had changed as they did. ${ }^{34}$ This accounting framework ignores the impact of changes in the industry-union distribution on the variance within each cell. The results indicate that 88 percent of the increase in the transitory variance is accounted for by changes in the variance within cells. Thus, compositional shifts are only a small part of the explanation.

\section{Job Turnover}

Changes in the effects of job turnover may also have resulted in greater fluctuations in earnings. There is widespread belief that the amount of job shifting not only increased during the 1980s but that the effects of such shifting became more uncertain. Popular accounts of the experience of young workers stress that while some young people successfully worked their way up job ladders others found themselves moving from job to job with little advancement. Likewise, older workers who change jobs are sometimes characterized as facing less predictable futures. Some have successfully negotiated firm restructurings while others have experienced large earnings losses because they could not find new positions at their old salaries. Earnings variability might, therefore, have increased because of job shifting.

We use the PSID to explore whether earnings variability increased for respondents who changed jobs and for those who stayed in the same job. The main issue is whether the variance of the transitory component increases within jobs. If so, this suggests that increased job shifting, even if it has occurred, is not the sole explanation for the patterns we have documented so far. The PSID asks respondents with more than one current job to identify their "main-job employer." They are also asked whether they had a different "main-job employer" at any point during the previous calendar year. ${ }^{35} \mathrm{We}$ define job changers as persons who re-

34. Using second-period weights and first-period variances gives similar results.

35. The way the question is asked creates a slight mistiming of the date of job change, since the individual could have changed jobs between January 1 and the interview date of the current year. Although the PSID began asking the date of any job change in recent interviews, it was not asked for most of the period of our data. We ignore this problem on the presumption that it is unlikely to have changed over time and, hence, to affect our estimates of trends. 
ported that they indeed had a different employer. ${ }^{36}$ Job changers are also asked the reason for leaving the previous job, thus allowing us to distinguish between voluntary and involuntary job changers. Involuntary job changers include persons who left their previous main job because the company folded, they were laid off or fired, or the job was "completed."

Identifying the effects of job changes on earnings is complicated by the annual time frame for measuring earnings in the PSID. If earnings data were available on a monthly basis, we could measure earnings before and after a job change, presuming the date of the job change were known. However, earnings data in the PSID, as in the majority of household surveys, are gathered on a calendar year basis. ${ }^{37}$ Therefore, we cannot measure precisely the change in earnings associated with a job change. The earnings in the year in which the job change takes place will instead be a mixture of the earnings from the new and old job. Persons who change jobs early in the year will have annual earnings that primarily reflect their earnings on the new job, and persons who change jobs late in the year will have earnings that largely reflect their earnings on the old job. This will also affect our estimates of transitory earnings in the years before and after the year of job change, since the difference in those earnings from earnings in the year of job change will depend partly on the (unknown) month in which the job change occurred. Given these issues, our measures of transitory earnings variances for job changers should be interpreted with caution. However, our main interest is whether the variance of transitory earnings has changed for individuals who never changed jobs, and for this group our transitory variance estimates are unaffected by these timing issues.

Figure 7 shows the transitory variances over the 1970-87 period for job stayers and job movers, who are further disaggregated in figure 8 ac-

36. Men who are currently unemployed but were employed during the previous year are also identified as job changers. However, men who were unemployed for all of the previous calendar year are excluded since they could not have separated from a job in that year; they are excluded from the denominator in all calculations of job changing probabilities. An alternative method of identifying job changers would be to count all respondents who reported time in current job as less than the elapsed time since the previous interview. This procedure, however, yields a substantial number of inconsistencies (see Brown and Light, 1992) and a time series that does not cover enough years for our study.

37. More recent interviews have collected information on intrayear earnings, however. 
Figure 7. Variance of Transitory Earnings by Job Status, 1970-87

Variance

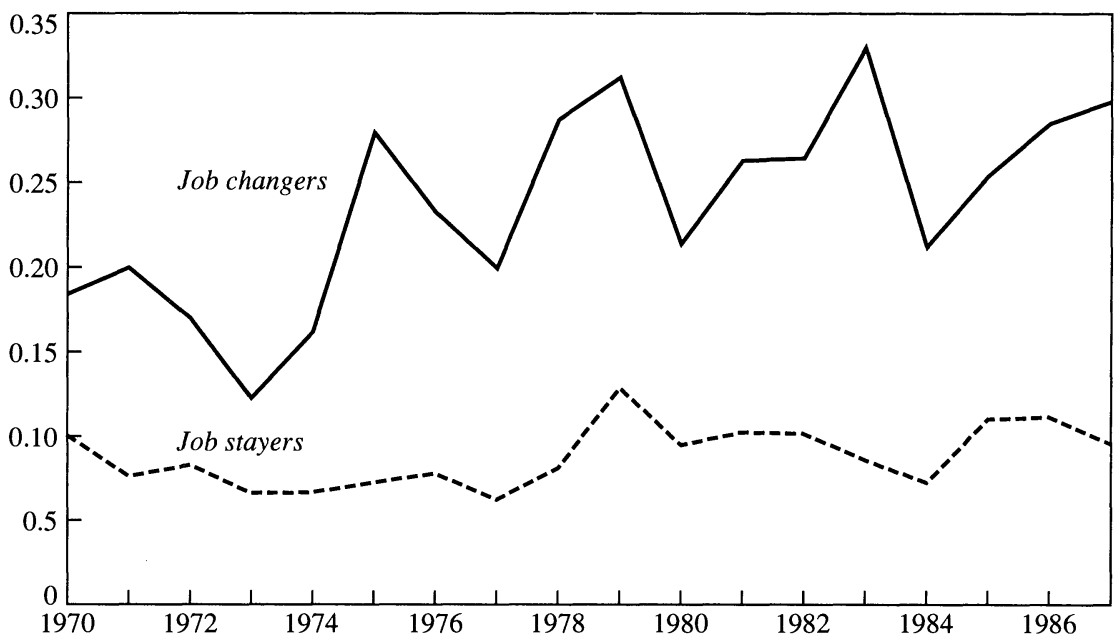

Source: Authors' tabulation of annual earnings of white male heads of households in the PSID.

a. Job status is determined by whether an individual reported changing "main-job" employer in the previous year.

Figure 8. Variance of Transitory Earnings by Voluntary and Involuntary Job Change, 1970-87a

Variance

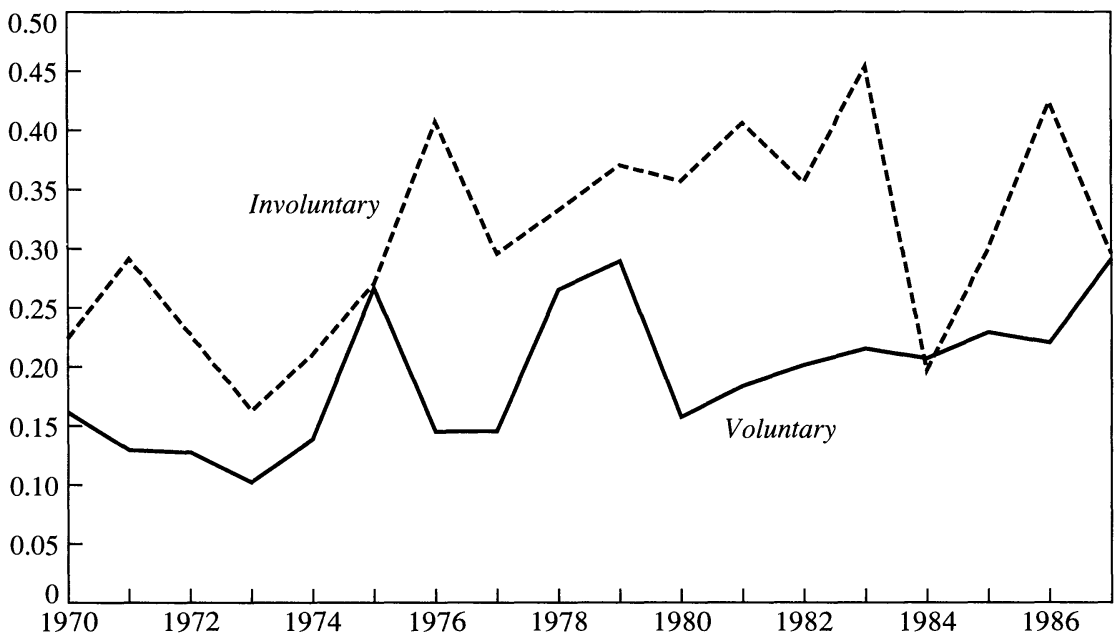

Source: Authors' tabulation of annual earnings of white male heads of households in the PSID.

a. Involuntary job changers are defined as individuals who left their previous main job because the company folded, they were laid off or fired, or the job was "completed." 
Table 4. Variance of Transitory Earnings by Job Status, Education, and Age, 1970-87 a

\begin{tabular}{|c|c|c|c|c|c|c|}
\hline \multirow[b]{2}{*}{ Sample definition } & \multicolumn{3}{|c|}{$\begin{array}{l}\text { Did not change jobs } \\
\text { within the period }\end{array}$} & \multicolumn{3}{|c|}{$\begin{array}{c}\text { Changed jobs at least once } \\
\text { within the period }\end{array}$} \\
\hline & $1970-78$ & $1979-87$ & Change & $1970-78$ & $1979-87$ & Change \\
\hline All & 0.047 & 0.064 & 0.017 & 0.122 & 0.174 & 0.052 \\
\hline \multicolumn{7}{|c|}{ Years of completed education } \\
\hline Fewer than 12 & 0.042 & 0.064 & 0.012 & 0.157 & 0.289 & 0.132 \\
\hline 12 or more & 0.049 & 0.065 & 0.016 & 0.109 & 0.149 & 0.040 \\
\hline 16 or more & 0.040 & 0.050 & 0.010 & 0.098 & 0.114 & 0.016 \\
\hline \multicolumn{7}{|l|}{ Age } \\
\hline $20-29$ & 0.079 & 0.093 & 0.014 & 0.142 & 0.195 & 0.053 \\
\hline $30-39$ & 0.041 & 0.065 & 0.024 & 0.113 & 0.147 & 0.034 \\
\hline $40-49$ & 0.039 & 0.044 & 0.005 & 0.097 & 0.168 & 0.071 \\
\hline
\end{tabular}

Source: Authors' calculations from the PSID.

a. Earnings data deflated to 1988 dollars.

cording to whether the move was voluntary or involuntary. ${ }^{38}$ Before the early 1980s, the variance of transitory earnings for job stayers showed no clear trend. However, during the 1980 s, fluctuations in transitory earnings were higher than in the 1970 s for both movers and stayers. The fact that men who stayed in the same job had larger fluctuations in earnings in the 1980s than in the 1970s suggests that job shifting was not the sole cause of the increased transitory earnings variance.

Table 4 shows transitory variances for both those who did not change their job within each of our nine-year subperiods and those who did change jobs within the subperiod. The most important result is that the variances for those who did not change jobs increased markedly between the periods, by more than a third (from 0.047 to 0.064 ). Increases in transitory variances also appear for those who changed jobs.

Was this increase in earnings fluctuation concentrated on the young or the less educated? As shown in the rest of table 4, the increase was widespread. All age and education groups found themselves with larger fluctuations in the 1980s than in the 1970s, whether or not they changed jobs. The fact that the young were not the only group to experience greater instability of earnings indicates that we are witnessing more than just an increased difficulty of the young in settling down into stable jobs.

38. The figure shows the variance of the transitory components of those who changed jobs in the year in question and those who did not. For the reasons noted above, there is some error in the calculation of these variances, but we presume that the job-stayer trends are not affected. 


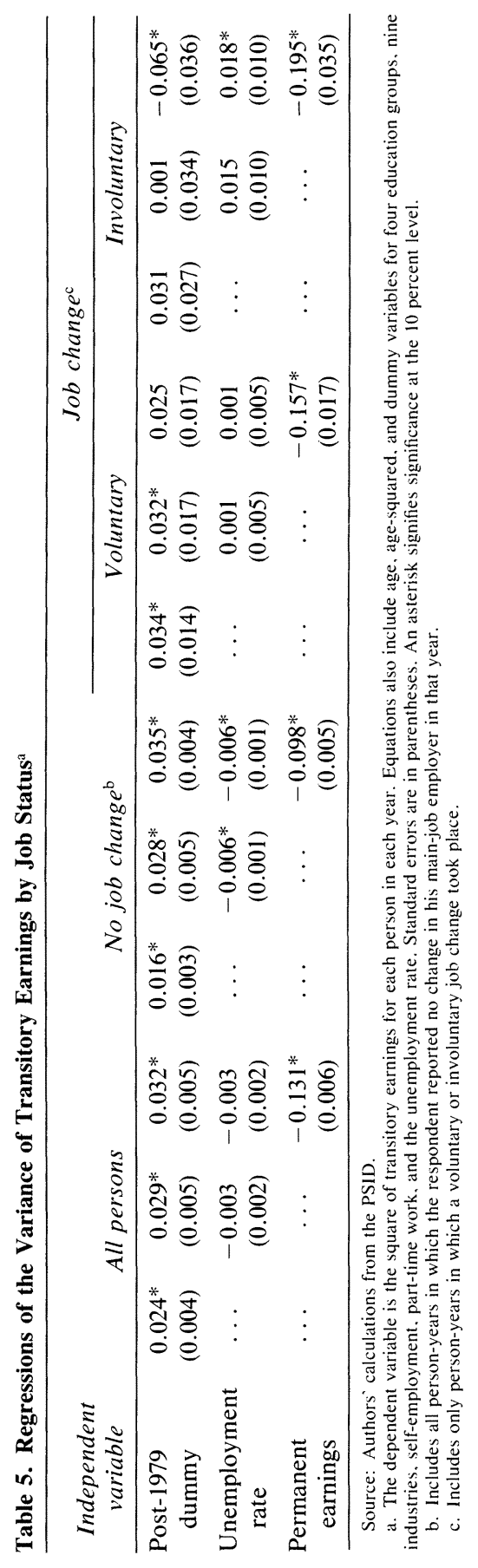


As for trends in the rate of job changing itself, the PSID shows an increase from the 1970 s to the 1980 s in the proportion of respondents reporting a change in main-job employer. Thus, the data suggest that part of the increase in overall earnings instability has resulted from increased job turnover. However, this increase in turnover is in contrast to tabulations based on the January CPS. Roughly every four years the CPS asks respondents how long they have been "working continuously for the same employer." Tabulations of the proportion who reports having been with their current employer for less than one year fluctuate but show no clear trend. ${ }^{39}$ Differences in the trends in job turnover between the CPS and PSID may reflect differences in the questions asked, the sample coverage (our PSID sample includes only household heads), or the years covered. The latter is particularly important since the CPS does not ask its job change question in every year. For example, the peak years of job turnover in the PSID are from 1984 to 1986 , which fall between the January 1983 and January 1987 surveys when job tenure questions were asked. In any case, while reconciliation of these two series is an important topic for future research, its resolution does not affect our main finding of increases in the transitory variance of job stayers, as we have emphasized, nor does it affect our trends in overall transitory variance. However, the exact size of the contribution of job changing remains to be determined. ${ }^{40}$

The tabular evidence in tables 3 and 4 controls for only a limited set of variables and ignores the fact that unemployment rates were higher in the 1980 s than in the 1970 s. Therefore, we present in table 5 regression results that control for age, education, self-employment status, parttime work, industry, and the unemployment rate. The dependent variable in the regressions is the squared transitory residual for each person in each year, the expected value of which is a consistent estimate of the

39. Tabulations in Farber (1994), Horvath (1982), and Sehgal (1984) indicate no trend for men after an initial increase between 1973 and 1978. Swinnerton and Wial (1993, table 9) show a decline in the proportion of respondents with an accumulated tenure of three years or fewer between 1979 and 1983, followed by an increase between 1983 and 1987 . We might note that the job tenure questions upon which these estimates are based presumably have the same inconsistency problems noted by Brown and Light (1992).

40. Our figures on the proportion of job stayers, whose variances are shown in table 4, agree with those of Hall (1982, table 1), who estimates a ten-year job retention rate of 27.6 percent for persons aged 30-34, in 1968. Our data show that one-third of the men did not change jobs in a nine-year period, very close to the Hall estimate. 
transitory variance. Separate results are also shown for regressions that control for the individual's level of permanent earnings (that is, our calculation of his mean earnings). ${ }^{41}$

The first three columns present results for all persons, while the remaining columns show results for nonmovers, voluntary job changers, and involuntary changers. The significant coefficients in the first three columns on the 1979-87 dummy variable indicate that transitory variances were higher during the 1980s than during the 1970s even after controlling for changes in unemployment and shifts toward types of employment with higher variances, such as shifts into part-time work or into high-variance industries, such as services. Furthermore, the magnitude of the change is substantial, since the sizes of the coefficients imply that the transitory variance was about one-third higher in the second period. The results in the fourth through sixth columns illustrate the importance of increased variability among men who did not change jobs. ${ }^{42}$ The table also shows that men who voluntarily changed jobs experienced an increase in transitory variance, whereas involuntary job changers did not. This evidence, therefore, reinforces our earlier finding that much of the increase in earnings instability also occurs among people staying in the same job.

The regressions that include the level of permanent earnings show that transitory variances are inversely related to that variable, consistent with evidence presented in table 1. More important, perhaps, the results indicate that transitory variances increase over time when the level of permanent earnings is held constant. Thus, taking the level of permanent earnings as a proxy for whether a job is "good" or "bad," our results show that transitory variance is not linked in a fixed way to the type of job.

In summary, we have shown that the increase in the transitory fluctuations in earnings is a broad phenomenon. It is not limited to labor market entrants or to men who change jobs because of plant closings or other involuntary terminations. Neither is it a purely compositional shift

41. The standard errors are not corrected for the panel nature of the data or for heteroscedasticity. Nor do we account for the fact that the permanent earnings variable is estimated from the same data used to create the dependent variable.

42. Since the decision to change jobs may have been influenced by the transitory variance, these results include the effect of moving and a potential selection effect. The results should, therefore, be interpreted solely as descriptive rather than as showing the effect of changing jobs on the transitory variance. 
toward nonunionized employment or toward industries with more variable earnings. Like the previous literature on earnings inequality, we have not found a smoking gun-a primary cause of the increased instability. Rather, we have ruled out certain explanations that are clearly inconsistent with the data.

\section{Fluctuations in Industry Aggregates}

All the evidence we have adduced thus far has been from individual longitudinal data. While the advantages of such data for the present issues are obvious, an important question is whether anything can be learned from wage and earnings data for the aggregate economy, or for subsectors within it, over the 1970s and 1980s. Such data are available from a variety of sources but most prominently from the Bureau of Labor Statistics (BLS).

Such data are very useful in determining the degree to which the transitory fluctuations in the PSID have as their origin fluctuations in economywide wages or sector-specific wages. Consider a modification of our model in equation 1 :

$$
y_{i j t}=\mu_{i}+\phi_{t}+\psi_{j t}+\tilde{v}_{i j t},
$$

where $j$ denotes the industry. The composite transitory error $v_{i t}$ in equation 1 is now disaggregated into three separate components: a year-specific effect $\left(\phi_{t}\right)$; an industry-year component $\left(\psi_{j t}\right)$; and a residual transitory component $\left(\tilde{v}_{i j t}\right)$, which now represents individual fluctuations within industries (net of aggregate movements by year). A transitory variance computed from equation 2 would equal the sum of the transitory variances of the last three terms, each of which has a zero mean and is assumed orthogonal to the other two. Transitory variance arising from the third component-individual variation within sectors over time-requires the use of individual longitudinal data; our work in prior sections has been designed to focus on that component. Here we turn to the transitory variance of the other two components.

Aggregating over individuals, we have

$$
\begin{gathered}
\bar{y}_{j t}=\bar{\mu}+\phi_{t}+\psi_{j t}, \quad \text { or } \\
\bar{y}_{j t}-\bar{\mu}=\phi_{t}+\psi_{j t} .
\end{gathered}
$$


Thus, the transitory variance of industry-specific log earnings $\left(\bar{y}_{j t}-\right.$ $\bar{\mu})$ - where the variance is taken over time $t$ with industry $j$ fixed-equals the sum of the variances of the two components on the right-hand side of equation 4. Transitory variance in the time-specific component $\left(\phi_{t}\right)$, that is, fluctuations in the economywide wage over time, informs us of the degree of instability in aggregate wages, while the variance over time of the second component $\left(\psi_{j t}\right)$, the industry-specific wage relative to the aggregate wage, tells us whether there is a sector-specific component to aggregate instability. The transitory variance of the former can be examined simply with the aggregate wage, while the transitory variance of the latter can be examined by computing the transitory variance of the lefthand side of

$$
\left(\bar{y}_{j t}-\bar{\mu}\right)-\phi_{t}=\psi_{j t},
$$

which is the log of the ratio of industry-specific wages in year $t$ to the aggregate wage in year $t$ (recall that $\bar{y}_{j t}$ is logarithmic).

The PSID data are in principle capable of being used to estimate these components, but the size of the sample does not permit disaggregation even at the major-industry level. For some industries there are fewer than 50 observations a year in our sample, thus effectively precluding a reliable estimate of fluctuations in sector-specific means, which would undoubtedly be dominated by sampling error. However, one issue that we can examine with the PSID data is the degree to which the total transitory variances we computed previously arise from variation in the year-specific and industry-specific means in the data. ${ }^{43}$ By simply recomputing our transitory variances after taking out year and industry effects-that is, using the residuals from regressions of log earnings on year and industry-year dummies-we can indirectly examine this issue. When this exercise is carried out, the transitory variance from 1970-78 to $1979-87$ increases by 47 percent, slightly more than the 42 percent shown in table 1. Although this indirectly implies that the underlying year and industry means must have become more, not less, stable between the periods, the PSID should not be relied on for a definitive answer to that question. However, this result does imply that the increase in transitory variance in the PSID is arising less from an increase in fluc-

43. The issue we examine here is different from the one we examined in the last section, where we were concerned with trends in within-industry transitory variance. 
tuations at the aggregate level than from idiosyncratic earnings fluctuations at the individual level.

To decrease sampling variability, we examine the aggregates themselves, using data from the Bureau of Labor Statistics on annual averages of real weekly earnings and real hourly earnings for the period $1970-93 .{ }^{44}$ These data cover only production and nonsupervisory workers, not the work force as a whole, thus introducing some noncomparability with the PSID. In addition, as with all aggregate data, the degree to which fluctuations in means over time arise from compositional changes (such as movements of individuals between sectors) cannot be examined. However, the large BLS sample with which the means are computed, as well as its availability for more recent years than the PSID, makes the data of independent interest.

Table 6 shows transitory variances calculated for log real average weekly earnings and log real average hourly earnings for workers as a whole. ${ }^{45}$ Between the same two periods we examined with the PSID data-1970-78 and 1979-87-the variance of weekly earnings increased slightly in the BLS data, while that of hourly earnings fell slightly. This is not strong evidence of an upward trend in aggregate volatility over the period. Moreover, when these data are adjusted for trend and cycle, as shown in the lower panel of the table, both variances decline. Thus, any evidence of an increase in the variability in weekly earnings appears to be the result of differences in average real growth between the two periods and in the business cycles of the 1970s and 1980s. This type of timeseries movement is quite different from the volatility we found in the PSID. ${ }^{46}$ Figure 9, which depicts the time series for BLS's mean log weekly earnings, shows that short-term volatility appears to be somewhat larger in the 1970-78 period than in the 1979-87 period even without adjustment. The apparent evidence shown in the top of table 6 of an increase in variability is, instead, a result of a more negative trend in earnings in the latter period than in the former period. Including a trend does not correspond to the usual notion of volatility.

44. These data are from unpublished BLS sources.

45. These are computed simply as the variance over time (within different subperiods) of the single series of weekly earnings or hourly earnings. Nine observations go into each variance calculation.

46. The transitory errors we computed in the PSID had a very low degree of serial correlation, unlike the transitory components in these aggregates. 
Table 6. Variance of Real Weekly Earnings and Real Hourly Earnings of Production and Nonsupervisory Workers, 1970-93

\begin{tabular}{ccc}
\hline $\begin{array}{c}\text { Adjustment and } \\
\text { sample period }\end{array}$ & $\begin{array}{c}\text { Log weekly } \\
\text { earnings }\end{array}$ & $\begin{array}{c}\text { Log hourly } \\
\text { earnings }\end{array}$ \\
\hline $\begin{array}{c}\text { Unadjusted } \\
\text { 1970-87 }\end{array}$ & \\
$1970-78$ & 0.039 & 0.037 \\
$1979-87$ & 0.056 & 0.026 \\
$1976-93$ & & \\
$1976-84$ & 0.049 & 0.014 \\
$1985-93$ & 0.066 & 0.073 \\
Adjusted for trend and cycleb & \\
$1970-87$ & & \\
$1970-78$ & 0.047 & 0.045 \\
$1979-87$ & 0.016 & 0.018 \\
$1976-93$ & & \\
$1976-84$ & 0.024 & 0.020 \\
$1985-93$ & 0.099 & 0.076 \\
\hline
\end{tabular}

Source: Authors' calculations from unpublished data from the Bureau of Labor Statistics.

a. Earnings are deflated by 1987 dollars using the personal consumption expenditure deflator. All variances are computed across the nine years in each subperiod and are multiplied by 100 .

b. Variances of the residuals from a regression on year and unemployment rate.

These results partly reflect the inclusion of the 1970-75 period, during which economic performance was quite different from that of later periods. Dropping these years and extending the examination through 1993, and performing the same transitory variance calculations for the 1976-84 and 1985-93 periods, show more consistent evidence for increased volatility, as also indicated in table 6 . The increase holds up for adjusted as well as unadjusted trends. However, as can be seen again in figure 9 , the increased volatility is primarily the result of the marked turnaround in real earnings growth after 1989, which is not highly correlated with the unemployment rate. Consequently, there appears to be more variability in the 1985-93 period simply because real wages fell and then rose before and after 1989. Once again, this is not evidence of highfrequency volatility.

\section{Industry-Specific Trends}

The lack of high-frequency volatility in the labor market as a whole is not surprising given that we are examining volatility at the aggregate 
Figure 9. Mean Log Weekly Earnings of Production Workers with Unemployment Rate, 1970-93

Log real earnings

Unemployment rate (percent)

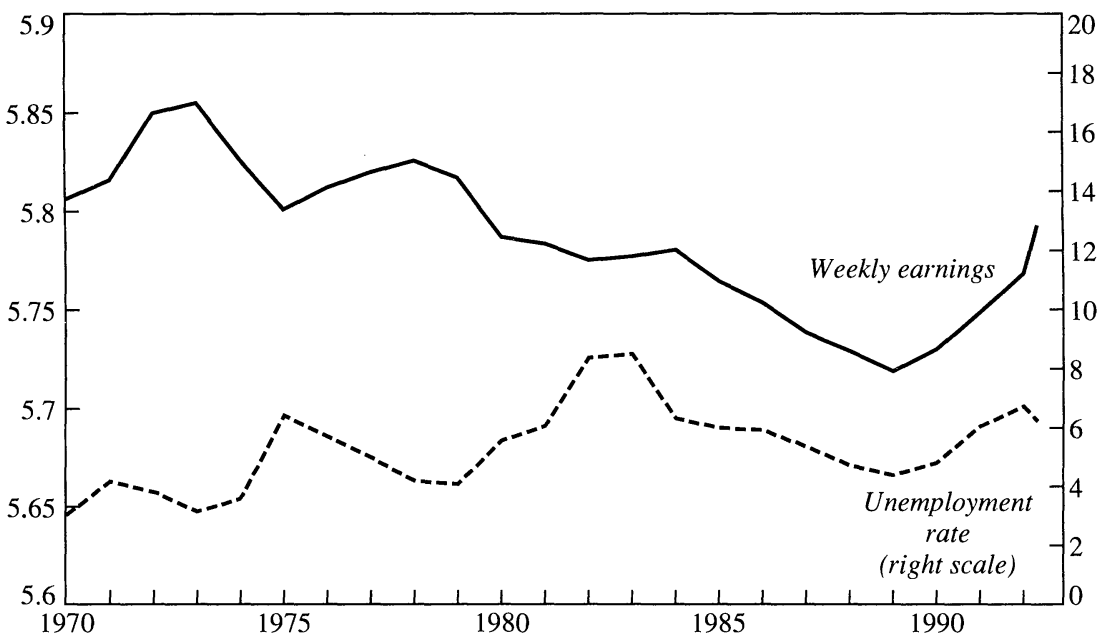

Source: Unpublished data from the Establishment Survey of the Bureau of Labor Statistics. The unemployment rate is taken from the Economic Report of the President, 1993. table B.37, p. 390.

level. Aggregate wages and earnings for the labor market as a whole do not exhibit high degrees of instability when averaged over the entire year; economywide annual wages and earnings move rather slowly. More likely to exhibit annual volatility are the relative industry-specific movements in earnings that we associated above with the symbol $\psi_{j t}$. This earnings component is defined as the log of the ratio of industry earnings to aggregate earnings. Scaling the industry earnings series by aggregate earnings serves to lessen the influence of the slow movements of the aggregate economy exhibited in figure 9.

Table 7 shows variance calculations for the two earnings components by major industry and how they change over the two pairs of time periods we have been considering. Interestingly, the change in the variance of unadjusted log weekly earnings and log hourly earnings between 1970-78 and 1979-87 is highly correlated with the mean level of those relative wages, since in every case those industries with mean earnings above the economywide average exhibit a decline in variability and those with mean earnings below the economywide average exhibit an 


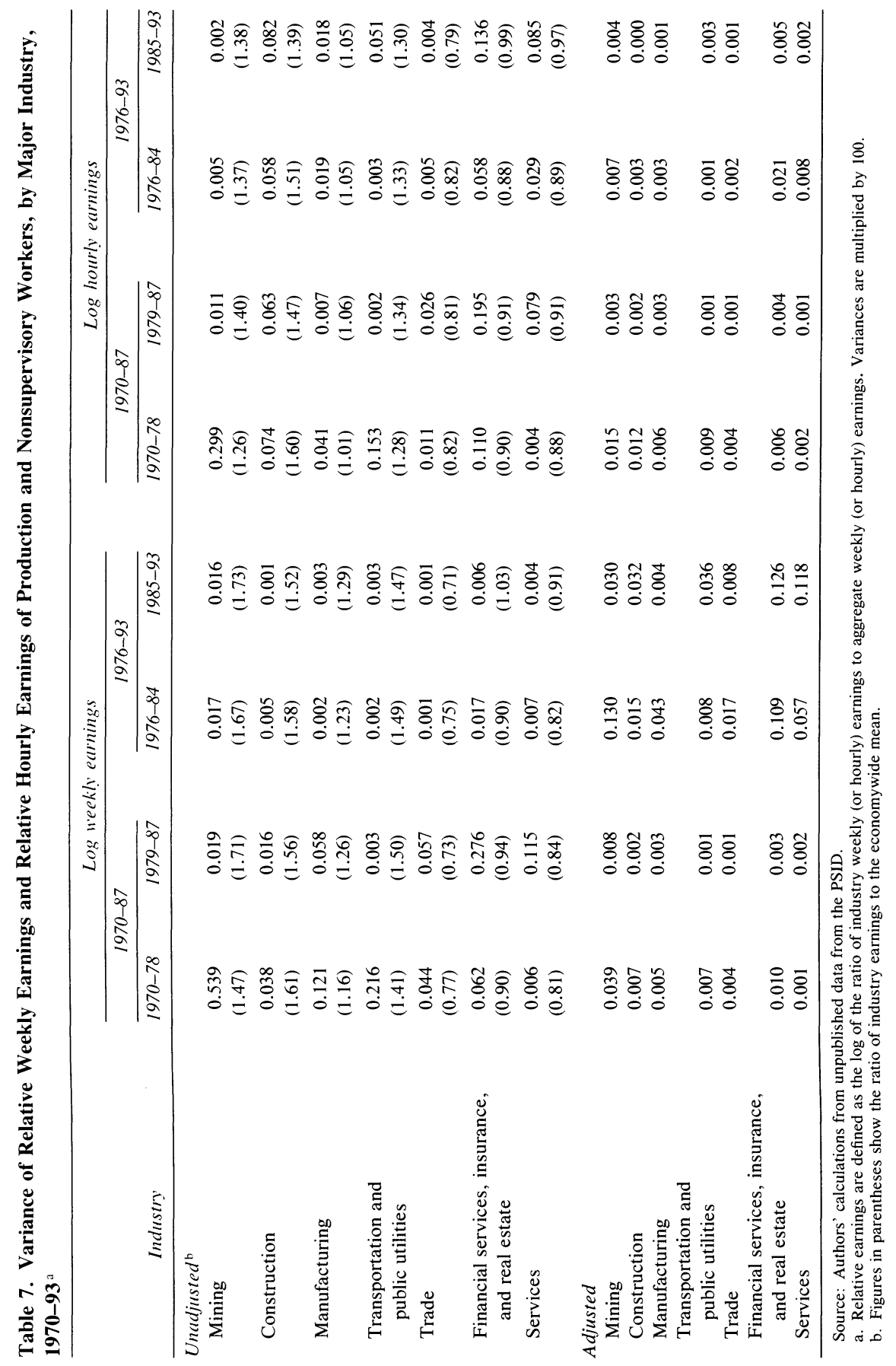


Figure 10. Relative Log Weekly Earnings by Industry, 1970-93 ${ }^{a}$

Relative log earnings

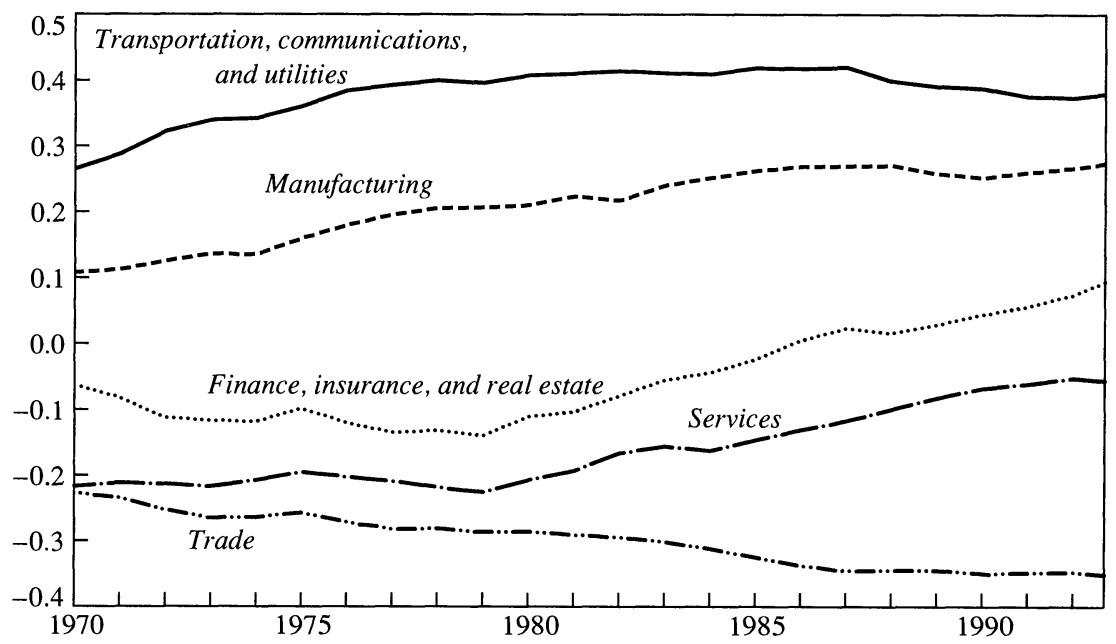

Source: Unpublished data from the Establishment Survey of the Bureau of Labor Statistics. a. Industry earnings are measured relative to aggregate earnings.

increase in volatility. This pattern is roughly consistent with many of the PSID findings showing stronger evidence of increases in transitory variance for those workers with below-average wages and earnings. Over the 1976-93 period, the pattern is not nearly so uniform, especially for weekly earnings, for which the increases and decreases in variability show no clear industrial pattern. However, for hourly earnings, a majority of sectors registers more volatility in this period than in the earlier one, consistent with some of the earlier aggregate evidence discussed above.

Despite this stronger evidence for an increase in sector-specific volatility in low-earnings industries, the time series for industry-specific relative earnings do not exhibit a high degree of volatility at the annual frequency. Figure 10 shows the trends for selected industries. Once again, it is clear from the figure that the main differences over time are the differences in trends in relative earnings within subperiods. There is no clear visual evidence of increased volatility at the annual frequency; the series again appear to be quite stable in the short run. The second portion of table 7, which shows the changes in variance after trend and cy- 
clical effects are removed, confirms the graphical evidence: almost all indications of increased variability over time disappear. ${ }^{47}$

While increased variability over the 1970s and 1980s arising from differences in trends and in the frequency of business cycles is of interest, it is quite distinct from the type of individual-level volatility we have uncovered with the PSID. Although smoother rates of output growth or more regularly occurring business cycles could, in principle, eliminate the former type of aggregate variability, it would have no necessary implication or consequence for the degree of individual volatility.

\section{Trends in Temporary Work and Firm Employment Dynamics}

There have been public and scholarly discussions of two factors that bear upon the increase in instability we have uncovered. One is the rise in temporary and contingent work, and the other concerns trends in job creation and destruction.

\section{Temporary Work}

Temporary work should be expected to be associated with high degrees of earnings fluctuation. For example, stories in the popular press concerning temporary office help or increases in the number of engineers working in "job shops" on temporary projects suggest that the prevalence of temporary work may have increased. Indeed, the evidence suggests that it has. In 1970, there were fewer than 200,000 employees in agencies that hired workers and placed them in temporary jobs in other firms; by 1992, there were more than 1,300,000 such workers. ${ }^{48}$ In a little more than two decades, employment of this type grew sevenfold. By 1982, employment in the temporary-help industry equaled that in the steel industry; by 1986, it had grown almost to equal employment in the auto industry; and by 1992 it had grown to exceed employment in the steel and auto industries combined. ${ }^{49}$

47. Separate adjustment for trend and cycle reveals, in fact, that differences in trend, not cycle, between the periods account for the transitory variance increases in the unadjusted figures. We should note that a further analysis using more detailed industry breakdowns, not reported here, fails to alter these results.

48. See National Association of Temporary Services (1993).

49. Employment and Earnings, 1986, table 61; 1990, table 63; 1994, table 65. 
Even these figures probably understate the size of this sector. Max Carey and Kim Hazelbaker speculate that the number of such workers may be 20 percent higher since many "job shops" that supply engineers and other nonmedical technical personnel on a short-term basis are probably classified in industries other than the temporary-help industry (such as engineering services). ${ }^{50}$ Likewise, Katherine Abraham estimates that including those workers employed by the firm itself to do short-term work or be on-call when additional workers are needed, as opposed to workers from a temporary-help firm, may double the number of temporary workers. ${ }^{51}$

While the temporary-help industry has been dominated by office workers, there has been a shift to nonoffice workers: office workers have dropped from two-thirds of temporary workers in 1972 to just over one-half in 1982. ${ }^{52}$ This difference indicates growth of higher-paid occupations in the temporary-help industry. For the same reasons, not all temporary work reflects stereotypical, and poorly paid, "contingent" work. Indeed, high-skilled workers may receive a wage premium for the variability of their earnings.

Despite these considerations, in 1992 the temporary-help industry still made up only slightly more than 1 percent of aggregate employment and can, at best, explain only a fraction of the increase in transitory earnings variance. ${ }^{53}$ Furthermore, as we documented previously, increases in transitory variances have not been confined to the services industry, where the official temporary-help industry is located. Still, temporary work and contingent work are poorly measured in available statistics, and such work may be represented more broadly in the labor market than initially appears. James Bond, for example, develops a broader definition of the contingent work force, one that is not limited to the services industry and is 20 times the magnitude of the official temporaryhelp industry. ${ }^{54}$ In addition, Abraham and Susan Taylor provide evidence that firms in several manufacturing industries increased their use of subcontractors from 1979 to 1986, which presumably is also associated with greater earnings volatility. ${ }^{55}$ Further research and improved

50. Carey and Hazelbaker (1986).

51. Abraham (1990).

52. See Abraham (1990, table 4.2).

53. See National Association of Temporary Services (1993).

54. Bond (1994).

55. Abraham and Taylor (1993, table 1). 
data collection would shed more light on the importance of this type of work arrangement.

\section{Firm Employment Dynamics}

Another literature that bears on earnings instability is that which examines job turnover at the firm or establishment level. ${ }^{56}$ This literature demonstrates that employment turnover at the establishment or plant level, as well as employment fluctuations generated by the birth and death of firms, is extremely high. Steve Davis and John Haltiwanger, for example, find that the annual sum of the rates of job creation and destruction in manufacturing is approximately 20 percent and that firm births and deaths account for 20 and 25 percent of annual job creation and destruction, respectively. ${ }^{57}$ This sum, although highly countercylical, is high at all stages of the business cycle. Another result from this literature is that the majority of plant- and establishment-level employment fluctuations are idiosyncratic and not explainable by aggregate or sectoral shocks. Timothy Dunne, Mark Roberts, and Larry Samuelson, for example, find that more than 70 percent of turnover in manufacturing plant-level employment occurs within the same region and same twodigit SIC industry. ${ }^{58}$

For our purposes, the major question is whether these firm- and establishment-level dynamics have changed over time. On this point, the evidence is relatively weak. Davis and Haltiwanger, for example, find no trend from 1973 to 1986 in the sum of job creation and destruction rates in manufacturing. ${ }^{59}$ In addition, Dunne, Roberts, and Samuelson find no strong trend in plant-level turnover in manufacturing from 1963 to $1982 .{ }^{60}$ Although their data are available only at five-year intervals, making it difficult to separate trend from cylical factors, and do not go past 1982, they are consistent with the Davis-Haltiwanger data.

While these studies reveal little evidence of trends in firm- and establishment-level employment turnover, the link between their findings and those we have presented is weakened by their exclusive focus on em-

56. See Leonard (1987), Davis and Haltiwanger (1990), Dunne, Roberts, and Samuelson (1989), and Anderson and Meyer (1994).

57. Davis and Haltiwanger (1990, pp. 125 and 133, table 1).

58. Dunne, Roberts, and Samuelson (1989).

59. Davis and Haltiwanger (1990, table 1). However, over time the fraction of gross job creation and destruction that is "permanent" (lasting more than a couple of years) has risen. See Davis, Haltiwanger, and Schuh (1994).

60. Dunne, Roberts, and Samuelson (1989, table 1). 
ployment dynamics rather than wage dynamics. As we demonstrated previously, much of the increase in earnings volatility in the 1980s has arisen within jobs, and earnings instability has also increased for job stayers. This implies that earnings volatility should have increased even in the absence of changes in employment turnover and other employment fluctuations. A useful area for future research, however, would be to examine earnings fluctuations at the plant and establishment levels with the data used in these prior studies. ${ }^{61}$

\section{Conclusions}

Prior studies using cross-sectional data have clearly documented that earnings became less equal in the 1980s. These data, however, cannot distinguish an increase in the dispersion of permanent earnings from an increase in the variability in earnings. The PSID data we have analyzed in this paper demonstrate that increased short-term fluctuations in earnings were roughly as important as increased dispersion of permanent (or average) earnings in accounting for increased cross-sectional inequality. Not only were the increases in transitory fluctuations large, but they were widespread. White males in all age and education groups experienced an increase in the variability of earnings. These effects were most pronounced among lower-wage workers.

The increase in the variance of permanent earnings is consistent with increases in the price of skill, but the increase in the variability of earnings may not be if the source of the skill-price increase is an increase in demand and a consequent increase in the relative quantities of highskilled, low-variability jobs. We find that other factors tend to make both weekly wages and weeks worked more variable. It is known, for example, that employment has shifted from manufacturing to services and trade, sectors that likely have more variable earnings. Likewise, the shift toward nonunionized employment is likely to have raised overall variability since unionized workers have more stable earnings. These compositional changes can account for only a small part of the increase in transitory earnings, roughly 12 percent. Likewise, greater mobility between jobs and the increase in self-employment and part-time work are not sufficient to account for the majority of the increase in variabil-

61. Davis and Haltiwanger (1991) use wage information from their data set but only to examine the cross-sectional variance of wages within and across plants. Presumably the same data could be used to examine wage variance within plants over time. 
ity. We have observed an increase in transitory fluctuations in the earnings of persons staying in the same job even after controlling for a wide variety of factors.

The aggregate data that we examine indicate that the increased variability is not primarily a result of increased instability in the labor market as a whole or in industry aggregates, consistent with the finding that industry shifts cannot explain much of the change. Although there is some evidence of increased variability of average industry wages, particularly for low-wage industries, this variability arises more from changes in medium-term trend rates than in high-frequency fluctuations that are ordinarily defined as transitory. Most of the increase in transitory variance appears instead to have occurred at the individual level.

Our search for explanations of the increase in transitory variance parallels the search conducted in the early studies of the causes of the increase in the level of earnings inequality - that is, whether shifts in industry mix, unionization, part-time work, and other factors can explain the trend. We have not located any definitive explanation for the increased transitory variance. This is a subject upon which future research may make additional progress.

\section{APPENDIX}

WE USE FORMULAS for permanent and transitory variances that are commonly given in many econometric textbooks. ${ }^{62}$ Let $y_{i t}$ be the value of $y$ for individual $i$ in year $t ; y_{i}$. be the mean of the $T_{i}$ values of $y_{i t}$ for individual $i$; and $y$. be the mean of $y_{i t}$ over all individuals and time periods. Also let $N$ be the number of individuals $(i=1, \ldots, N)$. The variance of the transitory component $(v)$ is computed as the mean, across people, of each of the individual transitory variances:

$$
\sigma_{v}^{2}=\frac{1}{N} \sum_{i=1}^{N} \frac{1}{\left(T_{i}-1\right)} \sum_{t=1}^{T_{i}}\left(y_{i t}-y_{i} .\right)^{2} .
$$

The variance of the permanent component $(\mu)$ is computed as

$$
\sigma_{\mu}^{2}=\frac{1}{N-1} \sum_{i=1}^{N}\left(y_{i} \cdot-y_{. .}\right)^{2}-\left(\sigma_{\nu}^{2} / \bar{T}\right),
$$

where $\bar{T}$ is the mean of $T_{i}$ over $i$.

62. See, for example, Johnston (1984, pp. 403-05). 


\section{Comments and Discussion}

Lawrence F. Katz: Peter Gottschalk and Robert Moffitt have produced an important paper that carefully documents and examines an apparently major labor market phenomenon that has been little noticed by mainstream labor economists but much speculated upon by the public and media: a substantial increase in earnings instability (transitory variation in earnings) in the United States since the end of the 1970s. Gottschalk and Moffitt uncover both a large growth in earnings fluctuations for those remaining in a single job and increases in job-changing rates from the 1970s to the 1980s in their analysis of data on adult white men from the Panel Study of Income Dynamics (PSID). These conclusions appear consistent (at least superficially) with the conventional wisdom put forward by publications such as Time that the economy has become increasingly individualistic and "cut-throat" and that there has been a substantial expansion of "contingent work" and "disposable jobs." An outstanding question is whether these results can be reconciled with other research using other data sets on earnings inequality and job stability.

Gottschalk and Moffitt find that increased transitory earnings variability has been an important contributor to a recent expansion in overall cross-sectional earnings inequality. Of course, the sharp increase in U.S. earnings inequality over the past 15 years or so is well known and has been carefully documented in a huge and growing literature for a large number of data sets and alternative measures of wages or earnings. ${ }^{2}$ This research finds that earnings inequality has been rising both between groups (for example, educational wage differentials have ex-

1. Janice Castro, "Disposable Workers," Time, March 29, 1993, p. 42.

2. See, for example, Karoly (1993), Katz and Murphy (1992), and Levy and Murnane (1992). 
panded) and within detailed demographic groups (for example, wage inequality has grown among individuals of the same age, sex, and educational attainment). Since the beginning of the 1980s, rising educational and occupational differentials have been a major factor in increased inequality. Thus, many researchers have emphasized interpretations focusing on rising returns to skill, presumably implying that most of the rise in inequality is associated with increased dispersion of relatively permanent earnings components. The findings of David Cutler and myself that rising income inequality has also been associated with rising consumption inequality also lends credence to the view that there has been an increase in inequality in permanent incomes (at least to the extent that one finds the permanent income hypothesis provides an adequate description of consumption behavior). ${ }^{3}$

Although increases in between-group wage differentials must by their very nature reflect increases in the dispersion of relatively permanent components of earnings variation, the sharp increase in within-group inequality could still reflect increases in transitory earnings instability. Gottschalk and Moffitt do confirm the conventional wisdom that most of the overall increase in earnings inequality for white males does reflect permanent factors, such as education and unmeasured permanent luck or skill components. In fact, they find that two-thirds of the increase in earnings variance from 1979 to 1987 has been in the permanent component. But they also find that the transitory earnings component (earnings instability) increased proportionally by the same amount as the permanent component and thereby (since transitory variation is half as large as permanent variation) contributed the remaining one-third of the increase in overall earnings variance.

Although most of the increase in inequality does fit the labor economists' conventional emphasis on skill differentials and other relatively permanent factors, the findings of Gottschalk and Moffitt suggest the need for more careful attempts to examine those factors potentially associated with increased earnings instability that have received much recent attention in the media-increased job instability, a growing contingent work force, less corporate loyalty, and increased downsizing. A gradual spread of these types of phenomena could show up as rising earnings instability over time.

3. Cutler and Katz (1991). 
Furthermore, the authors' findings reinforce the fractal nature of the rise in earnings inequality. Increased dispersion is apparent along essentially every dimension one cuts the data and appears to remain no matter how finely one cuts it. Inequality has increased between skill groups and within them, between sectors and within them, between establishments and within them, and along both permanent and transitory dimensions. The similarity in increases in dispersion along many dimensions does make it tempting to conclude that some common factors (such as skillbiased technological change, globalization, or changes in labor market institutions) could be driving expansions in both permanent and transitory earnings variation.

In the remainder of this comment, I would like to address three issues. First, I examine how plausible are Gottschalk and Moffitt's findings of rising earnings instability and increased job-changing rates and how consistent are these findings with research using other data sets. I conclude that their findings of transitory variation in earnings do appear plausible and should motivate further research on this topic. Second, I consider the extent to which explanations for rising skill differentials, such as skill-biased technological change, may also play a role in rising earnings instability. Third, I discuss evidence of institutional changes (deregulation, the demise of pattern bargaining, and so forth) that could lead to more individualistic wage setting both within and between establishments.

A first issue concerning the authors' finding of a substantial increase in transitory variance from the 1970s to the 1980s is whether it could be an artifact of the authors' approach to decomposing changes in overall earnings variance into transitory and permanent components. The primary approach used by the authors, in which permanent earnings are defined as average earnings over a nine-year period (after taking out a common life-cycle earnings profile), is the appropriate approach if one thought that there was a one-time shift in the variance of the permanent component in earnings between the 1970s and the 1980s. Yet most explanations for increases in the permanent component of earnings variation in the 1980s are based on gradual secular increases in the returns to skills not a one-time jump in the skill price. A simple model of permanent and transitory earnings components that captures this idea can be written as

$$
y_{i t}=p_{t} \alpha_{i}+v_{i t}
$$


where $y_{i t}$ is the log earnings of individual $i$ in year $t, \alpha_{i}$ is the time-invariant (permanent) earnings components (or skills) of individual $i, p_{t}$ is the time-varying price of skill, and $v_{i t}$ represents transitory earnings. If the actual story is one in which the price of skills $\left(p_{t}\right)$ was stable in the 1970s and then trended upward in the 1980s with little or no increase in transitory earnings variation (the variance of $v_{i t}$ ), then the authors' approach focusing on a one-time shift in permanent variance could attribute part of the increased variance from changes in skill prices to rising transitory variation. Nevertheless, the authors have shown that their finding of rising transitory variance is robust to a variety of alternative approaches to decomposing earnings into permanent and transitory components. Thus, while their primary decomposition approach (which is reflected in the paper's tables and figures) probably overstates the contribution of increases in transitory variance, the findings of substantial increases in earnings instability in the 1980s for white males in the PSID appear plausible and robust.

A second issue is whether the authors' conclusion of rising earnings instability is consistent with research using other data sets. Maury Gittleman and Mary Joyce have recently examined changes in earnings mobility over time using matched March Current Population Survey (CPS) data from 1967 to $1991 .{ }^{4}$ The CPS is designed so that households are in the survey for four months, exit for eight months, and then return for an additional four months. Thus, matched data from two consecutive March CPSs provide two consecutive years of data on annual earnings and weeks worked for a large nationally representative sample. ${ }^{5}$ Gittleman and Joyce find large increases in cross-sectional earnings variation in the 1980s but no decline in short-term earnings mobility (the extent of year-to-year movements across earnings quintiles) for either men or women. This result implies that transitory and permanent components of earnings variation have both increased by similar proportions, with the fraction of total cross-sectional earnings variance accounted for by permanent variance remaining essentially unchanged. The CPS findings

4. Gittleman and Joyce (1994).

5. The two major drawbacks of these matched March CPS data relative to the PSID for an analysis of earnings instability are that the matched CPS data follow individuals for only two years (making it difficult to examine alternative models of permanent and transitory earnings) and one loses from the sample all individuals who change residence between two survey dates. 
of Gittleman and Joyce are quite similar to previous findings by Moffitt and Gottschalk showing little change in short-term earnings mobility for white males in the PSID. ${ }^{6}$ Thus, both CPS and PSID data appear to indicate substantial increases in transitory earnings variation in the $1980 \mathrm{~s}$.

A final measurement issue concerns the authors' finding that much of the increase in earnings instability in the 1980s is associated with very large increases in job-changing rates (declining job stability and job retention rates). This finding does not appear to be consistent with other research using data from the CPS. Henry Farber finds little change in the distribution of job tenure during the 1980s. ${ }^{7}$ Francis Diebold, David Neumark, and Daniel Polsky also find no evidence of a decline in job retention rates during the 1980 s using the available CPS job tenure supplements. ${ }^{8}$ The difference between Gottschalk and Moffitt's striking finding of increased job instability in the PSID and findings of little change in similar measures for the CPS should motivate research into possible changes in the distribution of job durations and turnover rates in the 1980s and how changes may vary across demographic groups. Although Gottschalk and Moffitt do find increased earnings instability even among those that do not change jobs over a nine-year interval, much of the action reflects increases in transitory variation for job changers. Thus, it is crucial to better reconcile evidence on patterns of job retention rates in different data sets. Furthermore, it would be quite interesting to examine a decomposition of the overall increase in earnings instability into within- and between-job components.

The next issue I would like to examine is whether the hypotheses put forth to explain rising skill differentials and overall increases in wage inequality also provide plausible explanations for increases in transitory variance. The conventional wisdom is that increased skill differentials (increases in permanent earnings variation) have been driven by secular shifts in labor demand favoring more highly skilled and highly educated workers (problem solvers) and moving against less skilled and less educated workers (those doing more routine work). The rapid growth of the supply of college-educated workers in the 1970s driven by the influx of the baby-boom cohort into the labor market and incentives for further education caused by the Vietnam War draft outstripped these demand

6. Moffitt and Gottschalk (1993).

7. Farber (1994).

8. Diebold, Neumark, and Polsky (1994). 
shifts and led to narrowing education differentials in the 1970s. In the 1980 s, the growth of the relative supply of more educated workers decelerated and demand shifts against less educated workers probably accelerated because of skill-biased technological change (the spread of computers) and unbalanced expansions in international trade accompanied by large trade deficits. Increased immigration of less educated workers may also have slightly weakened the labor market performance of lowwage workers in the 1980s. Two institutional changes also put downward pressure on the wages of non-college-educated workers-the decline in unionization and the erosion of the real value of the minimum wage. The much larger increase in wage inequality in the United States than in other OECD nations (with the exception of Great Britain) in the 1980 s probably relates to differences in wage-setting institutions that have made relative wages much more responsive to market shifts in the United States. ${ }^{9}$ Changes in skill demand and the decline in institutional factors affecting wage setting could have contributed to increased earnings instability.

How could a shift in labor demand favoring more educated workers and problem-solving skills be associated with increased earnings instability? Such an outcome could arise if the shift in labor demand is driven by skill-biased technological change and the gradual spread of new technologies and approaches to organizing work. To the extent that the latter are being introduced, more workers are like new workers. Learning models predict that earnings instability (temporal wage variation) is greater for workers in a new job or early in their careers because more information is rapidly revealed about their overall ability and match-specific productivity at such times. If the spread of computers and new work practices in the 1980s made more workers like new workers, then one might expect an increase in earnings instability. An outstanding question is whether this is a transitional phenomenon during a shift to a more computer-oriented work place or whether it could be a continuing process inherent in technologies that constantly evolve with changes in software.

Changes in labor market institutions may also have significantly increased earnings instability by leading to more individualistic wage setting both within and between establishments during the 1980s. Daniel

9. Freeman and Katz (1994). 
Mitchell has described the decline of "pattern bargaining" in the union sector and national wage setting by many firms as the "demacroization" of wage setting. ${ }^{10}$ Spot-market wage setting is likely to lead to more fluctuations in wages than administered wages. The decline of unions and the erosion of the minimum wage have both weakened institutions that lent stability to the wages of workers in the lower part of the earnings distribution. A role for these factors is consistent with Gottschalk and Moffitt's finding that the increase in earnings instability has been concentrated among those in the lower half of the permanent earnings distribution. The rapid growth of temporary work in the 1980s and early 1990s is also consistent with their findings but not large enough to be a major part of the story.

Three further tidbits of evidence appear to be related to rising earnings instability. The first is that local labor market conditions appear to have had a stronger relationship to individual earnings in the 1980s than in the 1970s. ${ }^{11}$ The second is that industries that deregulate appear to have large increases in earnings variation and develop stronger links between pay and firm characteristics. ${ }^{12}$ The third is that many employers appear much more intent on linking pay to individual and firm performance, and contingent pay has grown, such as the use of lump-sum bonuses. ${ }^{13}$ The movement from an economy with wage "contours" and expectations dominated by visible settlements in the large firm-unionized sector of the economy to one where pay is more related to local conditions and idiosyncratic factors may be part of the story of increased earnings instability.

Moffitt and Gottschalk's intriguing findings should provide a starting point for research on the extent to which rising earnings and job instability are robust features of increased earnings inequality in the 1980s and the extent to which institutional changes related to the demacroization of the economy play a role. But the search for explanations for increased transitory earnings instability should not lead one to lose track of the fact that the majority of rising earnings inequality is driven by increases in the variation in permanent earnings (related to rising returns to education, skills, and connections).
10. Mitchell (1989).
11. Katz and Krueger (1991).
12. See, for example, Card (1989) on the airline industry.
13. Mitchell (1989). 
William T. Dickens: This is a very interesting and provocative paper. It analyzes a new dimension of the growing income inequality-the volatility of income. The authors find that income volatility has grown substantially and that the increase in volatility has been greatest for the poor and the least skilled. These are important and disturbing findings, and, if they prove to be as robust as the main facts about growing inequality, they add another facet to an already bleak picture.

Peter Gottschalk and Robert Moffitt also explore many possible causes of growing income volatility and effectively narrow the range of possible explanations. Finally, the authors catalog a daunting array of facts about the dynamics of the changing structure of earnings. Some of these facts may help us understand not only the growth in the volatility of income but also the causes of the growing dispersion of permanent income as well.

I have three main comments on this work. First, I want to raise some doubts about the generality of the results. Specifically, I suggest that it is important to examine the issues raised in this paper using other data sets (for other demographic groups) and to update the analysis. Second, I will discuss the implications of these findings for people's well-being. In particular, I want to comment on the relationship between this paper and other evidence on the effect of growing income inequality on consumption patterns. Finally, I will discuss what light this paper might shed on the causes of the growing variability of permanent income.

\section{Doubts about Generality}

Gottschalk and Moffitt use the Panel Study of Income Dynamics (PSID) from 1970 to 1987 to study the changing distribution of income for white male heads of households who are between the ages of 20 and 50. Although much of the work on growing income inequality has focused on this group, we know from a wide range of studies that the now familiar facts of growing inequality and increasing returns to education and experience are common to all demographic groups. Yet, let me suggest some reasons why the authors' decomposition of changes into permanent and transitory components would not hold for other data sets, for other demographic groups, and for different ending dates.

I find Gottschalk and Moffitt's result showing large increases in the fraction of workers changing jobs each year surprising. As they note, the 
Table 1. Men with Current Employer for Less Than a Year Percent

\begin{tabular}{ccc}
\hline Year & 16 and older & 25 and older \\
\hline 1981 & 24.8 & 17.8 \\
1983 & 24.7 & 18.0 \\
1987 & 25.9 & 19.1 \\
1991 & 24.5 & 18.8 \\
\hline
\end{tabular}

Source: Various January editions of the Current Population Survey. The question was not asked in 1985 or 1989.

Current Population Survey (CPS) shows only a very small increase in the number of people who stay with their employer for less than a year between 1981 and 1987. Further, there is a decline in this fraction after 1987 in the CPS. I have reproduced these CPS figures in my table 1. Gottschalk and Moffitt's analysis of the PSID shows an increase from 1981 to 1987 in the number of people who say they have been in their current job for less than a year that is three to four times greater than that found in the CPS for roughly comparable demographic groups.

Similarly, work by Kenneth Swinnerton and Howard Wial suggests a relatively small secular increase in the rate of job changing. ${ }^{1}$ A new paper by Francis Diebold, David Neumark, and Daniel Polksy also analyzes the CPS and finds no evidence of an increase. ${ }^{2}$ An analysis I did last year for the Economic Report of the President, 1994 shows no secular increase in the rate of reallocation of workers between industries in the 1970 s or 1980 s. $^{3}$

Gottschalk and Moffitt do not tell us how much of their increase in transitory earnings variance is due to job changing, but examination of figures 7 and 8 suggests that a lot of what is not accounted for by rising unemployment is accounted for by an increase in the rate of job changing. This suggests that an analysis using the panel aspect of the CPS might find that a substantially smaller fraction of the increase in variance is transitory.

Further, the CPS shows a decline in the rate of job changing in the early 1990s. If the paper's decomposition was done comparing the 1970s to the late 1980s and early 1990s, the story might be different again.

1. Swinnerton and Wial (1993).

2. Diebold, Neumark, and Polsky (1994).

3. Economic Report of the President, 1994, table 3-15. 
Finally, the CPS data suggest something that Dave Marcotte has shown starkly - that there are large differences between demographic groups in what has happened to job stability. ${ }^{4}$ Although some groups have seen substantial declines in stability, for others jobs have become more stable. Older white males have seen a decline in job stability. Thus, the decomposition of the change in variance into permanent and transitory components may be very sensitive to the demographic group analyzed.

\section{Consumption and Permanent versus Transitory Changes}

There are probably many reasons why we care about the decomposition of growing inequality into permanent and transitory components. One is that increases in transitory income variance may have less of an impact on consumption and welfare than increases in permanent variance. Economists often assume that people can use savings, borrowing, and other devices to smooth short-run fluctuations in incomes. People's consumption need not vary as much as their income.

In their paper,Gottschalk and Moffitt find that about one-third of the growth in inequality is due to growth in short-run variability. In a previous paper on the changes in the autocovariance structure of earnings, they found that about half of the overall increase in inequality was due to increased short-run variability. ${ }^{5}$ One might conclude from this that the problem of increasing inequality is only one-half to two-thirds as bad as we had previously thought. A third to a half of the increase is only transitory and easily smoothed.

The definition of transitory in this paper would not support such a conclusion since a "transitory" deviation here is any deviation from a seven-year average. A promotion, which causes what an individual might view as a very permanent increase in income, would cause an increase in transitory variance as it is measured here. However, in the authors' previous work they decompose income into three components: a permanent individual effect, a purely transitory effect, and a permanent change or random-walk component. They find increases in the variance of all components, but only the increases in the permanent individual effect and the pure transitory component are statistically significant and

4. Marcotte (1994).

5. Moffitt and Gottschalk (1993). 
large. Further, they estimate the persistence of the pure transitory component, and it is very short lived. Three-fourths of any transitory change is gone after one year and nearly all of it is gone after three or four years. Thus, the one-half of the increase in inequality they attribute to transitory variance in their previous work is due to shocks that last less than a year. Does this mean that the importance of the increased inequality for welfare is overstated when cross-sections are compared? Other evidence suggests that it is not.

David Cutler and Lawrence Katz have analyzed the change in family income and the change in consumption by quintile. ${ }^{6}$ They find that changes in consumption and income were proportional in four out of five of the quintiles. Consumption changes were significantly less than proportional only for the second-highest quintile, which saw relatively little change in income. This suggests that either people view the changes in income that have widened the earnings distribution as more permanent than Gottschalk and Moffitt's analysis suggests, or people cannot or do not smooth even relatively short-lived changes in income. With respect to the first possibility recall my earlier doubts about generality. With respect to the second, recent work by Jonathan Gruber shows that insurance against spells of unemployment is incomplete. ${ }^{7}$ Most spells of unemployment last less than a year. Despite this, the loss of income causes a noticeable fall in consumption that cannot be explained away as the result of a fall in expected earnings. Thus, a large transitory component to the increase in inequality as measured in this paper could still be consistent with the proportional change in consumption found by Cutler and Katz.

In fact, Cutler and Katz find that declines in consumption are more than proportional to changes in income for the lowest quintile. The difference is small and could be due to measurement error, or Gottschalk and Moffitt's other major finding might explain this. Perhaps the concentration of the increase in volatility at the bottom of the income distribution is forcing people there to expend resources to buffer consumption against increased income variance. In any case, the fact that variance is increasing more at the bottom of the distribution probably has welfare consequences. Even with constant relative risk aversion, a greater dif-

6. Cutler and Katz (1992).

7. Gruber (1994). 
ficulty in accessing capital markets for those with lower incomes would imply welfare effects for the distribution of variability.

\section{What Do We Learn about the Causes of Increased Inequality?}

Besides its implications for welfare, we also might care about decomposing permanent and transitory components of increasing earnings variation if it taught us something about the likely causes of that increase. There has been considerable frustration over how large the increase in unexplainable or residual earnings inequality has been. Some have reacted to this by noting that increasing returns to education and experience probably reflect increases in the return to skills. Since we measure skill very poorly (usually only years of education and years of potential work experience), it is reasonable to believe that increasing returns to the unobserved component of skills could explain a lot of the increase in residual earnings.

But Gottschalk and Moffitt point out that such an explanation is hard to square with their finding that a third to a half of all increasing variation in earnings is due to an increase in year-to-year changes. I think they are only partially right. The fact that the lion's share of the increase in transitory variation is occurring among those with the least education, and the lowest permanent income, invites some skepticism about this claim. The increase in transitory variance must have something to do with ability.

One part of the explanation may be variability in employment. About 40 percent of the increase in the authors' estimate of the transient component results from an increase in the variability of weeks worked; the other 60 percent comes from increasing weekly earnings variation. We know that unemployment tends to be concentrated-occurring in lumps that come and go in the space of a year. If less able workers have seen a fall in their productivity, this could affect the length and frequency of their unemployment spells. This could be a result of voluntary labor supply or the reaction of employers paying above-market clearing wages (such as those that result from minimum wages, rent sharing, or the payment of an efficiency wage). Given the lumpiness of unemployment spells, increasing unemployment for the less skilled would show up primarily as an increase in transitory variance for those workers.

Another part of the explanation could be increases in the amount of temporary part-time work. Again, variation in weekly hours could re- 
flect lowered labor supply in the face of falling opportunity or of constraints on labor supply for those with less ability. To determine the importance of unemployment and temporary part-time work, it would be interesting to see a version of table 1 on the variance of hourly wages.

If 40 percent of the increase in transitory variance is due to variability of employment, which could reflect the effects of an increasing skill premium, then there is not much left that cannot be explained as increasing returns to skills. Only a third of the increase in overall inequality is transitory, so we are down to about 20 percent of the increase in variance being due to transitory changes in weekly earnings, which might be hard to explain as being due to an increasing skill premium. I expect that most advocates of the increasing skill premium as an explanation would be willing to accept the possibility that 20 percent of the increase might be due to other causes. However, this is not end of the story.

It is impossible to tell for sure from this paper but, if a substantial portion of the increase in transitory variance of wages (as opposed to income) is concentrated among the less educated and among those with low earnings, this is a real anomaly. I would think that those who believe that returns to skills are the explanation would expect the opposite. Why would transitory fluctuations in real earnings increase over time? One possibility is that the matching of skills with job demands is not always perfect-skilled individuals may find themselves temporarily forced to take employment in jobs that do not utilize their skills. However, someone with little skill can hardly suffer an income loss from not being able to use that skill. I would think that we would expect an increase in the return to skills to raise the short-run variability of earnings most for those with the highest skills. I would urge the authors to examine this issue directly in future work.

\section{General Discussion}

The panel began with a discussion of the welfare implications of the paper's findings. Gary Burtless cautioned against interpreting the results as showing that increases in inequality are more benign than previously thought. He noted that two-thirds of the increase is still attributed to permanent factors, leaving a welfare problem even if transitory shocks were considered unimportant to welfare. Furthermore, he suggested that transitory variance is also likely to lower welfare. For the risk averse, greater variance of income reduces utility, particularly for 
those without assets or access to the capital market to smooth consumption. And transitory variance increased most for those in the lowest part of the income distribution, implying a greater loss in utility for that group.

Edmund Phelps suggested that discussions of the welfare consequences of greater transitory variance need to distinguish between two sources of transitory variance-wage rate variation and employment variation. He suggested that an increase in wage rate instability is less of a problem than a widening of the distribution of average wages. Insofar as increased transitory variance reflects wage flexibility, it means that labor markets are working more efficiently, which should be as welcome as increased price flexibility. Furthermore, individuals can take measures to soften the impact of transitory losses, and the welfare state offers additional insurance. In his view, efforts to make incomes more secure and insulate individuals from market signals would be the wrong response.

Some panelists raised questions about the decomposition of income into permanent and transitory components. They suggested that, by defining transitory income as any deviation from the mean within each nine-year period, shocks to income that were actually permanent may be labeled transitory. Robert Hall suggested that a random walk is a more natural model for permanent income, which would allow the permanent component to change within each nine-year period. Lawrence Katz noted that the authors' earlier paper on this topic uses a random walk decomposition and reaches similar conclusions to the current paper.

The authors acknowledged that a more sophisticated decomposition would have advantages but argued it was desirable to use as simple a decomposition as possible. They noted that there are many ways to decompose income into permanent and transitory components, each of which involves an arbitrary judgment. Although the magnitude of the estimated increase in transitory variance is affected, the overall story stands whether the decomposition is done using the manner of the previous paper, that of the current paper, or moving averages to calculate permanent income. Robert Moffitt noted that the serial correlation between an individual's successive transitory components is low (about 0.4 ), suggesting that these shocks are largely transitory and that the estimates are not significantly affected by their simplification. Katz responded that the serial correlation might be understated because of measurement error in 
the survey, raising the possibility that their decomposition still contains spurious transitory components.

William Nordhaus asked about the covariance of the incomes of individuals within the same family in the 1980s. The lower the correlation of family members' incomes, the more muted would be the welfare effects of higher income variance, because income changes within a family would more likely be offsetting. Katz cautioned that transitory shocks can be correlated across related individuals because the employment status of individuals in the same local labor market tends to be correlated. Burtless noted that the covariance of family members' incomes went up substantially between 1979 and 1989 . He added that part of the explanation is an increase in the labor supply of women married to highincome men.

Jack Triplett wondered how the decline in unionization affected the variance of permanent income. Because union members tend to earn a wage premium relative to nonunion members, Triplett expected declining unionization to narrow the distribution of permanent income. William Dickens noted other research indicating that unions narrow the within-union wage distribution. Because this effect outweighs the effect of the income premiums associated with unionization, greater unionization actually reduces aggregate earnings inequality. Moffitt added that the education-based categories used in the paper are too broad for unionization to make much difference.

The authors also responded to Dickens' question about whether increased job turnover in the PSID sample-as compared with the relative constancy of turnover in the CPS-might be the key to explaining the paper's results. Moffitt noted that transitory variance increased even for workers who stayed on the same job. Also, he and Gottschalk have verified that the pattern of cross-sectional income variance in the PSID matches that of the CPS. This fact provides some comfort but still leaves open questions about the role of job turnover.

Gregory Mankiw suggested that a longer historical perspective could change the interpretation of the recent widening of the income distribution. The Census Bureau's data on the size distribution of income indicate that the recent widening has only brought the income distribution back to where it was in 1950 . Katz noted that for wage income alone, inequality has risen to its level in 1940, the end of the Great Depression. Putting the 1940 distribution into perspective, however, is difficult because we know little about what happened between 1900 and 1940 . 


\section{References}

Abraham, Katharine G. 1990. "Restructuring the Employment Relationship: The Growth of Market-Mediated Work Arrangements." In New Developments in the Labor Market: Toward a New Institutional Paradigm, edited by Katharine G. Abraham and Robert B. McKersie. Cambridge, Mass.: MIT Press.

— and Evidence." Working Paper No. 4468. Cambridge, Mass.: National Bureau of Economic Research (September).

Anderson, Patricia M., and Bruce D. Meyer. 1994. "The Extent and Consequences of Job Turnover." BPEA, Microeconomics, 177-236.

Becketti, Sean, and others. 1988. "The Panel Study of Income Dynamics after Fourteen Years: An Evaluation." Journal of Labor Economics 6(4): 472-92.

Blackburn, McKinley L., David E. Bloom, and Richard B. Freeman. 1990. "The Declining Economic Position of Less Skilled American Men." In A Future of Lousy Jobs? The Changing Structure of U.S. Wages, edited by Gary Burtless. Washington: Brookings.

Bond, James T. 1994. "Preliminary Examination of the Contingent Workforce." Unpublished paper. Washington: Families and Work Institute (March).

Bound, John, and George Johnson. 1992. "Changes in the Structure of Wages in the 1980s: An Evaluation of Alternative Explanations." American Economic Review, 82(3): 371-92.

Bound, John, and Alan B. Krueger. 1991. "The Extent of Measurement Error in Longitudinal Earnings Data: Do Two Wrongs Make a Right?" Journal of Labor Economics 9(1): 1-24.

Bound, John, and others. 1994. "Evidence on the Validity of Cross-Sectional and Longitudinal Labor Market Data." Journal of Labor Economics 12(3): 345-68.

Brown, James, and Audrey Light. 1992. "Interpreting Panel Data on Job Tenure." Journal of Labor Economics 10(3): 219-57.

Card, David E. 1989. "Deregulation and Labor Earnings in the Airline Industry." Working Paper 247. Princeton, N.J.: Industrial Relations Section, Princeton University (January).

Carey, Max L., and Kim L. Hazelbaker. 1986. "Employment Growth in the Temporary Help Industry." Monthly Labor Review 109(4): 37-44.

Cutler, David M., and Lawrence F. Katz. 1991. "Macroeconomic Performance and the Disadvantaged." BPEA, 2:1991, 1-61.

- 1992. "Rising Inequality? Changes in the Distribution of Income and Consumption in the 1980s." American Economic Review 82(2): 546-51.

Davis, Steven J., and John Haltiwanger. 1990. "Gross Job Creation and Destruction: Microeconomic Evidence and Macroeconomic Implications." In NBER Macroeconomics Annual 1990, edited by Olivier Jean Blanchard and Stanley Fischer. Cambridge, Mass.: MIT Press. 
1991."Wage Dispersion between and within U.S. Manufacturing Plants, 1963-86." BPEA, Microeconomics, 115-80.

presented at G-7 conference. Washington: Center for Economic Studies, U.S. Bureau of the Census.

Diebold, Francis X., David Neumark, and Daniel Polsky. 1994. "Job Stability in the United States." Working Paper 4859. Cambridge, Mass.: National Bureau of Economic Research (September).

Dooley, Martin D., and Peter Gottschalk. 1984. "Earnings Inequality among Males in the United States: Trends and the Effect of Labor Force Growth." Journal of Political Economy 92(1): 59-89.

Dunne, Timothy, Mark J. Roberts, and Larry Samuelson. 1989. "Plant Turnover and Gross Employment Flows in the U.S. Manufacturing Sector." Journal of Labor Economics 7(1): 48-71.

Farber, Henry S. 1994. "Are Lifetime Jobs Disappearing? Job Duration in the United States: 1973-1993." Unpublished paper. Princeton University.

Fitzgerald, John, Peter Gottschalk, and Robert Moffitt. 1994. "A Study of Sample Attrition in the Michigan Panel Study of Income Dynamics." Unpublished paper. Brown University.

Freeman, Richard B., and Lawrence F. Katz. 1994. "Rising Wage Inequality: The United States vs. Other Advanced Countries." In Working Under Different Rules, edited by Richard B. Freeman. New York: Russell Sage Foundation.

Friedman, Milton. 1957. A Theory of the Consumption Function. Princeton, N.J.: Princeton University Press.

Gittleman, Maury, and Mary Joyce. 1994. "Earnings Mobility and Long-Run Inequality: An Analysis Using Matched CPS Data." Unpublished paper. Bureau of Labor Statistics, U.S. Department of Labor.

Goldin, Claudia, and Robert A. Margo. 1992. "The Great Compression: The Wage Structure in the United States at Mid-Century." Quarterly Journal of Economics 107(1): 1-34.

Gottschalk, Peter, and Robert Moffitt. 1992. "Earnings and Wage Distributions in the NLS, CPS, and PSID." Part I of Final Report to the U.S. Department of Labor. Brown University (May).

Gruber, Jonathan. 1994. "The Consumption-Smoothing Benefits of Unemployment Insurance." Unpublished paper. Massachusetts Institute of Technology.

Hall, Robert E. 1982. "The Importance of Lifetime Jobs in the U.S. Economy." American Economic Review, 72(4): 716-24.

Hill, Martha S. 1992. The Panel Study of Income Dynamics: A User's Guide. Newbury Park, Calif.: Sage Publications.

Horvath, Francis W. 1982. "Job Tenure of Workers in January 1981.” Monthly Labor Review' 105(9): 34-36.

Johnston, J. 1984. Econometric Methods, third ed. New York: McGraw-Hill.

Juhn, Chinhui, Kevin M. Murphy, and Robert H. Topel. 1991. "Why Has the 
Natural Rate of Unemployment Increased Over Time?" BPEA, 2:1991, 75126.

Karoly, Lynn A. 1993. "The Trend in Inequality among Families, Individuals, and Workers in the United States: A Twenty-Five Year Perspective." In Uneven Tides: Rising Inequality in America, edited by Sheldon Danziger and Peter Gottschalk. New York: Russell Sage Foundation.

Katz, Lawrence F., and Alan B. Krueger. 1991. "Changes in the Structure of Wages in the Public and Private Sectors." In Research in Labor Economics: A Research Annual, vol. 12, edited by Ronald G. Ehrenberg. Greenwich, Conn.: JAI Press.

Katz, Lawrence F., and Kevin M. Murphy. 1992. "Changes in Relative Wages, 1963-1987: Supply and Demand Factors." Quarterly Journal of Economic's 107(1): 35-78.

$\rightarrow$ Lawrence, Robert Z. 1984. "Sectoral Shifts and the Size of the Middle Class." Brookings Review 3(1)(Fall): 3-11.

Leonard, Jonathan S. 1987. "In the Wrong Place at the Wrong Time: The Extent of Frictional and Structural Unemployment." In Unemployment and the Structure of Labor Markets, edited by Kevin Lang and Jonathan S. Leonard. New York: Basil Blackwell.

Levy, Frank, and Richard J. Murnane. 1992. "U.S. Earnings Levels and Earnings Inequality: A Review of Recent Trends and Proposed Explanations." Journal of Economic Literature 30(3): 1333-81.

Marcotte, Dave E. 1994. "The Declining Stability of Employment in the U.S.: 1976-1988." Unpublished paper. University of Maryland (April).

Mitchell, Daniel J. B. 1989. "Wage Pressures and Labor Shortages: The 1960s and 1980s." BPEA, 1989:2, 191-231.

Moffitt, Robert, and Peter Gottschalk. 1993. "Trends in the Covariance Structure of Earnings in the United States: 1969-1987." Discussion Paper 1001-93. Madison, Wisc.: Institute for Research on Poverty, University of Wisconsin.

Murphy, Kevin M., and Finis Welch. 1992. "The Structure of Wages." Quarterly Journal of Economics 107(1): 285-326.

National Association of Temporary Services. 1993. "Temporary Help Industry Continues to Lead Employment Recovery." NATS Press Release, June 18.

Reynolds, Morgan O., and Eugene Smolensky. 1976. Why Changing the Size Distribution of Income Through the Fisc is Now More Difficult: Hypotheses from U.S. Experience. Madison, Wisc.: Institute for Research on Poverty, University of Wisconsin.

Sehgal, Ellen. 1984. "Occupational Mobility and Job Tenure in 1983." Monthly Labor Review 107(10): 18-23.

Swinnerton, Kenneth, and Howard Wial. 1993. "Is Job Stability Declining in the U.S. Economy?" Economic Discussion Paper 42. Washington: U.S. Department of Labor (September).

Williamson, Jeffrey G., and Peter H. Lindert. 1980. American Inequality: A Macroeconomic History. New York: Academic Press. 